\title{
Evaluation of near-surface ozone over Europe from the MACC reanalysis
}

\author{
E. Katragkou ${ }^{1}$, P. Zanis ${ }^{1}$, A. Tsikerdekis ${ }^{1}$, J. Kapsomenakis ${ }^{2}$, D. Melas ${ }^{3}$, H. Eskes ${ }^{4}$, J. Flemming ${ }^{5}$, V. Huijnen ${ }^{4}$, \\ A. Inness ${ }^{5}$, M. G. Schultz ${ }^{6}$, O. Stein ${ }^{6}$, and C. S. Zerefos ${ }^{2}$ \\ ${ }^{1}$ Department of Meteorology and Climatology, School of Geology, Aristotle University of Thessaloniki, Thessaloniki, Greece \\ ${ }^{2}$ Research Centre for Atmospheric Physics and Climatology, Academy of Athens, Athens, Greece \\ ${ }^{3}$ Laboratory of Atmospheric Physics, School of Physics, Aristotle University of Thessaloniki, Thessaloniki, Greece \\ ${ }^{4}$ KNMI, De Bilt, the Netherlands \\ ${ }^{5}$ ECMWF, Reading, UK \\ ${ }^{6}$ Forschungszentrum Jülich, Jülich, Germany \\ Correspondence to: E. Katragkou (katragou@auth.gr)
}

Received: 30 December 2014 - Published in Geosci. Model Dev. Discuss.: 5 February 2015

Revised: 10 July 2015 - Accepted: 13 July 2015 - Published: 30 July 2015

\begin{abstract}
This work is an extended evaluation of nearsurface ozone as part of the global reanalysis of atmospheric composition, produced within the European-funded project MACC (Monitoring Atmospheric Composition and Climate). It includes an evaluation over the period 20032012 and provides an overall assessment of the modeling system performance with respect to near-surface ozone for specific European subregions. Measurements at rural locations from the European Monitoring and Evaluation Program (EMEP) and the European Air Quality Database (AirBase) were used for the evaluation assessment. The fractional gross error of near-surface ozone reanalysis is on average $24 \%$ over Europe, the highest found over Scandinavia (27\%) and the lowest over the Mediterranean marine stations (21\%). Near-surface ozone shows mostly a negative bias in winter and a positive bias during warm months. Assimilation reduces the bias in near-surface ozone in most of the European subregions - with the exception of Britain and Ireland and the Iberian Peninsula and its impact is mostly notable in winter. With respect to the seasonal cycle, the MACC reanalysis reproduces the photochemically driven broad spring-summer maximum of surface ozone of central and south Europe. However, it does not capture adequately the early spring peak and the shape of the seasonality at northern and north-eastern Europe. The diurnal range of surface ozone, which is as an indication of the local photochemical production processes, is reproduced fairly well, with a tendency for a small overes-
\end{abstract}

timation during the warm months for most subregions (especially in central and southern Europe). Possible reasons leading to discrepancies between the MACC reanalysis and observations are discussed.

\section{Introduction}

The European projects MACC (Monitoring Atmospheric Composition and Climate) and MACC-II (Interim Implementation) were established under the umbrella of the European Copernicus programme, formerly known as GMES (Global Monitoring for Environment and Security), to build and demonstrate a core capability for providing a comprehensive range of services related to the chemical and particulate composition of the atmosphere (Hollingsworth et al., 2008; Flemming et al., 2009; Inness et al., 2013). Within MACC operational forecasts of atmospheric composition on global (Stein et al., 2012) and regional scale are produced. Furthermore, the MACC reanalysis (Inness et al., 2013) provides global atmospheric composition fields which can be used to serve as boundary conditions for regional air quality models over Europe and world-wide.

The MACC global model used for both reanalysis and forecasts consists of the European Center for Medium-Range Weather Forecasts' (ECMWF) Integrated Forecast System (IFS) coupled to the MOZART-3 (Kinnison et al., 2007) 
chemistry transport model. The ECMWF modeling system makes use of its data-assimilation capabilities to combine observations of atmospheric composition with the numerical model in order to produce a reanalysis of atmospheric composition (Inness et al., 2009, 2015). ECMWF has many years of experience in producing reanalysis products, starting from ERA-40 (Dethof and Holm, 2004) and continuing with ERA-Interim (Dragani, 2010, 2011).

Evaluation of MACC data is being done on a regular basis (Eskes et al., 2015) and specifically for trace gases in the global troposphere (e.g. Stein et al., 2014) and the stratosphere (e.g. Lefever et al., 2014). The global reanalysis products are mostly used as a reference data set for specific case studies (e.g. Knowland et al., 2014) or as boundary conditions for international activities, like the Air Quality Modeling Evaluation International Initiative-AQMEII (Air Quality Modeling Evaluation International Initiative) starting from phase I (e.g. Schere et al., 2012) up to its current phase III. It is therefore useful to have a systematic analysis on a key atmospheric species of the global reanalysis product (i) as a reference for those wishing to use it in their studies and (ii) as a general assessment of the system performance, identifying potential issues needing further improvement.

In this work special emphasis is given on the evaluation of near-surface ozone over Europe for the whole reanalysis period produced within MACC (2003-2012). Near-surface ozone is one of the main pollutants affecting both human health and vegetation (Fuhrer and Booker, 2003; Scebba et al., 2005; Schlink et al., 2006). Sources of tropospheric ozone can be either the stratosphere-troposphere transport or the photochemical production through oxidation of VOCs (volatile organic compounds) and $\mathrm{CO}$ in the presence of adequate $\mathrm{NO}_{x}\left(\mathrm{NO}_{x}=\mathrm{NO}_{2}+\mathrm{NO}\right)$ concentrations (Lelieveld and Dentener, 2000). Ozone can be destroyed photochemically or by dry deposition at the surface. Ozone precursors have natural as well as anthropogenic sources, the most important of which are emissions from soil, vegetation and fossil fuel combustion. Ambient ozone concentrations depend strongly on availability and relative abundance of those precursors but they are also modulated by the meteorological conditions (Davies et al., 1992; Bloomfield et al., 1996; Baertsch-Ritter et al., 2004; Hegarty et al., 2007; Kalabokas et al., 2008).

The issue of the short-term and long-term ozone variability is complex, being related to changes of anthropogenic and natural emissions, meteorological conditions, atmospheric boundary layer mixing processes and stratospheretroposphere exchange. Although a number of measures aimed at reducing $\mathrm{NO}_{x}$ and VOC emissions have been effective in reducing concentration of precursor species (Vestreng et al., 2009) and peak ozone values in Europe (EMEP/CCCReport $1 / 2005,2005)$, there are many studies suggesting that background tropospheric ozone levels (even near the surface) are increasing (Chevalier et al., 2007; Ordóñez et al., 2007; Hess and Zbinden, 2013; Wilson et al., 2012; Akritidis et al.,
2014). However, Parrish et al. (2012) reported a slower rate of increase over the last decades at European sites, to the extent that at present $\mathrm{O}_{3}$ is decreasing at some sites, mostly in summer.

Furthermore, although the current consensus view is that photochemistry is the major contributor to the observed background ozone levels in the troposphere, there is still no consensus as to the mechanisms that lead to the formation of the spring ozone maximum observed in certain locations of the Northern Hemisphere, distant from nearby pollution sources (Crutzen et al., 1999; Lelieveld and Dentener, 2000; Monks, 2000; Zanis et al., 2007). The spring ozone maximum observed in certain locations of the Northern Hemisphere, distant from nearby pollution sources, has mainly two contributions; (i) the stratosphere to troposphere transport (STT) (Stohl et al., 2003 and references therein) and (ii) ozone production in the troposphere on a hemispherical scale, related to photochemical processing of precursor tropospheric trace gases $\left(\mathrm{CO}, \mathrm{NO}_{x}, \mathrm{VOCs}\right)$ built up in winter (Penkett and Brice, 1987) and the longer lifetime of ozone during winter that allows anthropogenically produced ozone to accumulate (Lie et al., 1987; Yienger et al., 1999).

In this paper we evaluate near-surface ozone of the MACC reanalysis over Europe from 2003 to 2012. We provide an overall assessment of the model performance, putting special emphasis on the reproduction of annual and diurnal cycles. When possible, we provide potential explanations for model inabilities to reproduce specific observational characteristics of certain subregions and finally we suggest points of future work.

\section{Methodology}

\subsection{Global model}

The IFS includes greenhouse gases (Engelen et al., 2009) and aerosols (Benedetti et al., 2009; Morcrette et al., 2009). In MACC, the MOZART-3 chemistry transport model has been coupled to the IFS to provide chemical tendencies for ozone, carbon monoxide, nitrogen oxides and formaldehyde (Flemming et al., 2009), while chemical data assimilation for these species takes place in IFS (Inness et al., 2009, 2015). MOZART- 3 as used in the MACC reanalysis system is described in Stein et al. (2012, 2013).

A data assimilation system for aerosol, greenhouse gases and reactive gases is in place based on ECMWF's 4D-VAR data assimilation system. The fields of MACC reanalysis (hereafter MRE) are available globally at a horizontal resolution of $\sim 80 \mathrm{~km}$ (T159 spectral resolution) and 60 hybrid sigma-pressure levels from the surface up to $0.1 \mathrm{hPa}$. More details on the CTM and the IFS configurations and the data assimilation system are provided by Inness et al. (2015) and references therein. A combination of profile and total column ozone retrievals was assimilated in MRE, namely GOME, 
Table 1. Ozone satellite retrievals that were assimilated in the MACC reanalysis. PROF denotes profile data, TC total columns, PC partial columns, and SOE solar elevation. PC SBUV/2 data consist of six layers between the surface and $0.1 \mathrm{hPa}$. NRT (near-real time) data are available within a few hours after the observation is made, and are being used in operational forecast systems. For periods towards the end of the MACC reanalysis period, NRT data were used for some of the species when no offline products were available.

\begin{tabular}{|c|c|c|c|c|c|c|c|}
\hline Sensor & Satellite & Provider & Version & Period (yyyy/mm/dd) & Type & Data usage criteria & Reference \\
\hline GOME & ERS-2 & RAL & & $2003 / 01 / 01-2003 / 05 / 31$ & $\mathrm{O}_{3} \mathrm{PROF}$ & $\begin{array}{l}\text { Used if } \mathrm{SOE}>15^{\circ} \text { and } \\
80^{\circ} \mathrm{S}<\text { lat }<80^{\circ} \mathrm{N}\end{array}$ & Siddans et al. (2007) \\
\hline MIPAS & ENVISAT & ESA & & 2003/01/27-2004/03/26 & $\mathrm{O}_{3} \mathrm{PROF}$ & All data used & Carli et al. (2004) \\
\hline MLS & AURA & NASA & V02 & $\begin{array}{l}2004 / 08 / 08-2009 / 03 / 15 \\
\text { NRT data from } 20090316\end{array}$ & $\mathrm{O}_{3} \mathrm{PROF}$ & All data used & Waters et al. (2006) \\
\hline OMI & AURA & NASA & V003 & $\begin{array}{l}\text { From } 2004 / 10 / 01, \text { NRT data } \\
2007 / 03 / 21-2007 / 12 / 31\end{array}$ & $\mathrm{O}_{3} \mathrm{TC}$ & Used if $\mathrm{SOE}>10^{\circ}$ & $\begin{array}{l}\text { Bhartia et al. (2002); } \\
\text { Levelt et al. (2006) }\end{array}$ \\
\hline SBUV/2 & NOAA-16 & NOAA & V8 & From 2004/01/01 & $\mathrm{O}_{3} \mathrm{PC}$ & Used if $\mathrm{SOE}>6^{\circ}$ & Bhartia et al. (1996) \\
\hline SBUV/2 & NOAA-17 & NOAA & V8 & From 2003/01/01 & $\mathrm{O}_{3} \mathrm{PC}$ & Used if $\mathrm{SOE}>6^{\circ}$ & Bhartia et al. (1996) \\
\hline SBUV/2 & NOAA-18 & NOAA & V8 & From 2005/06/04 & $\mathrm{O}_{3} \mathrm{PC}$ & Used if $\mathrm{SOE}>6^{\circ}$ & Bhartia et al. (1996) \\
\hline SCIAMACHY & ENVISAT & KNMI & & From 2003/01/01 & $\mathrm{O}_{3} \mathrm{TC}$ & Used if $\mathrm{SOE}>6^{\circ}$ & Eskes et al. (2005) \\
\hline
\end{tabular}

MIPAS, MLS, OMI, SBUV/2, SCIAMCHY (Table 1) using ECMWF's 4D-Var assimilation algorithm (Courtier et al., 1994). For a more detailed description of the assimilation setup see Inness et al. (2013). It should be noted that no tropospheric ozone data were assimilated, so that the impact of the assimilation on near-surface ozone comes from the residual of assimilating stratospheric and total column ozone. More details on the impact of stratospheric ozone assimilation in tropospheric ozone is provided by Lefever et al. (2014).

Since several satellite instruments are used to assimilate one parameter in the data assimilation system, a bias correction method is applied to the data to account for the instrumental inconsistencies. In MRE a variational bias correction scheme for radiance data has been extended to atmospheric composition data (Inness et al., 2013). In the variational scheme biases are estimated during the analysis by including bias parameters in the control vector. The bias corrections are continuously adjusted to optimize the consistency with all information used in the analysis. The impact of assimilation on near-surface ozone is only the residual of correcting the stratospheric and total ozone column, plus the assimilation of other relevant gases that impact ozone chemistry $(\mathrm{CO}$, $\mathrm{NO}_{2}$ ) (Inness et al., 2013). The impact of the assimilation of tropospheric $\mathrm{NO}_{2}$ columns from the Ozone Monitoring Instrument (OMI) is small because of the short lifetime of $\mathrm{NO}_{2}$ (Inness et al., 2015).

To investigate the impact of assimilation on key atmospheric species, a control run was also performed (hereafter CTRL), using the same reanalysis settings without assimilation. As explained in Inness et al. (2013) (Sect. 2.5), it would have been computationally too expensive to produce a control analysis experiment that was identical to the MACC reanalysis, but did not actively assimilate observations of reactive gases. Instead, a MOZART-3 stand-alone run was carried out that applied the same settings (model code, resolution, emissions) as MOZART in the MACC reanalysis. The meteorological data for the stand-alone run were taken from the reanalysis, but the control run had free-running chemistry. The results from this control run can be used to detect the impact of the assimilation of greenhouse reactive gases observations in the MACC reanalysis. Since the meteorological input data were derived from interpolation of archived 6-hourly output from the MACC reanalysis, and not through an hourly exchange as in the reanalysis, the stand-alone run was not a completely clean control run. However, these differences would be small. The comparison between the MRE and the CTRL is confined to the time period 2003-2010, when both time series are available.

\subsection{Observations}

Measurements from ground based European stations were used for the evaluation of modeled surface ozone, from the European Monitoring and Evaluation Programme (EMEP) and the European Environment Agency databases (AirBase) covering the time period from 2003 to 2012. The observations used for this evaluation are independent from the assimilated ones. EMEP is appropriate to evaluate coarse resolution simulations, as it is fitted to catch background air pollution patterns with stations at a considerable distance from source areas in rural or remote regions (Schaap et al., 2015). Only background rural stations have been used from the AirBase database for comparisons with the coarse resolution model surface ozone. These include stations class 1-3 according to the Joly-Peuch classification methodology for surface ozone (Joly and Peuch, 2012). There is a total of 138 stations included in the current analysis, fulfilling the abovementioned criteria. This selection ensures that all stations are adequate for comparisons with coarse resolution $(80 \mathrm{~km})$ model data.

Observed data from the EMEP and AirBase database were available in hourly resolution, while model values were available in 3-hourly intervals. The corresponding observational data were extracted with a 3-hourly interval, to be compa- 
rable with modeled time-series. The modeled data were extracted from the coupled system by means of interpolating surface ozone into each station location. Different model levels were used for comparison with ground-based stations. The rationale behind the selection of different model level selection instead of extracting time series from the first model level (surface) is that in coarse resolution grids, areas with anomalous terrain (e.g. mountainous areas) are represented with an average elevation, which is less than the actual station elevation. Based on the difference between the actual station altitude and the average grid-cell elevation, the corresponding model level is selected, using atmospheric pressure as the correction criterion. We have used only those stations that fulfil the criteria of $75 \%$ data availability for near-surface ozone.

In order to acquire a more detailed view of model performance, eight European subregions have been defined as shown in Fig. 1. These regions fit data coverage and avoid overlapping between each subregion. The eight European subregions are: Britain and Ireland (BI), France (FR), Iberian Peninsula (IP), Eastern Europe (EA), middle Europe (ME), Mediterranean (MD), south-middle Europe (SME) and Scandinavia (SC). Furthermore, the Mediterranean region was further split into the continental part (MDc) and the marine part $(\mathrm{MDm})$, according to their spatial location (coastal or interior continental), since each type of station has different characteristics.

Additional $\mathrm{NO}$ and $\mathrm{NO}_{2}$ data are included in the analysis, in order to assess the potential of the photochemical ozone production. The $\mathrm{NO}$ and $\mathrm{NO}_{2}$ were extracted from EMEP and AirBase. Unfortunately the number of EMEP stations that provide $\mathrm{NO}$ and $\mathrm{NO}_{2}$ measurements - besides ozone - for the whole reanalysis period (2003-2012) is limited (30 stations). After application of the station type classification for ozone and the data availability criteria, only three subregions with both $\mathrm{O}_{3}$ and $\mathrm{NO}_{x}$ measurements remained, namely Britain and Ireland (BI) with 10 stations, Iberian Peninsula (IP) with eight stations and Middle Europe (ME) with 12 stations. The plots referring to ozone and nitrogenspecies comparison correspond to a smaller number of the common stations mentioned above, always being a subset of the total.

We have also to take into consideration that the $\mathrm{NO}_{x}$ observations are affected strongly by local emissions. Furthermore, there are known issues with interference by oxidized nitrogen compounds (e.g. $\mathrm{HNO}_{3}$, PAN and other organic nitrates) for ground-based $\mathrm{NO}_{2}$ measurements by most commercially available $\mathrm{NO}_{2}$ instruments using molybdenum converters, hence leading to an overestimation of $\mathrm{NO}_{x}$ concentrations (Steinbacher et al., 2007).

Ozonesondes are used to validate ozone MRE profiles into the troposphere at six European stations: Haute-Provence $\left(43.9^{\circ} \mathrm{N}, 5.7^{\circ} \mathrm{E}\right)$, Hohenpeissenberg $\left(47.8^{\circ} \mathrm{N}, 11^{\circ} \mathrm{E}\right)$, Legionowo $\left(52.4^{\circ} \mathrm{N}, 20.9^{\circ} \mathrm{E}\right)$, Payerne $\left(46.8^{\circ} \mathrm{N}, 6.9^{\circ} \mathrm{E}\right)$, Sodankyla $\left(67.4^{\circ} \mathrm{N}, 26.6^{\circ} \mathrm{E}\right)$ and Uccle $\left(50.8^{\circ} \mathrm{N}, 4.3^{\circ} \mathrm{E}\right)$. The

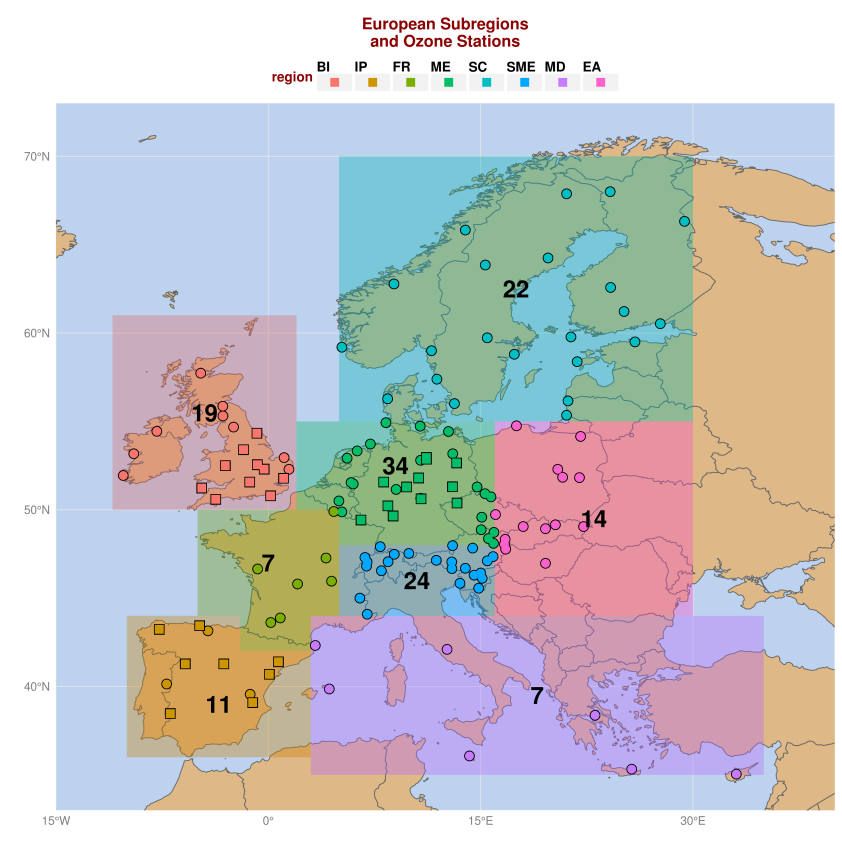

Figure 1. The European subregions that were used in the analysis and the corresponding EMEP and AIRBASE stations. The numbers denote the number of stations taken into consideration for every subregion. The subregions are: Britain and Ireland (BI), France (FR), Iberian Peninsula (IP), Eastern Europe (EA), middle Europe (ME), Mediterranean (MD), south-middle Europe (SME) and Scandinavia (SC).

sondes used for the validation come from Network for the Detection of Atmospheric Composition Change (NDACC; ftp://ftp.cpc.ncep.noaa.gov/ndacc/station). The precision of electrochemical concentration cell ozonesondes in the troposphere is between -7 and $+17 \%$ below $200 \mathrm{hPa}$ (Komhyr et al., 1995).

\subsection{Metrics and intercomparison methodology}

For the current evaluation study we use statistical metrics to quantify the bias, gross error and temporal correlation of the model with regards to observational surface ozone. Comparisons of the diurnal ranges and cycles are also performed, as indices of photochemical processes. As is also discussed by Savage et al. (2013), spatial and temporal variations in chemical composition, including tropospheric ozone, can be large, while also differences between model and observed values are frequently much larger in magnitude than usual for meteorological variables. Therefore, mean error and root mean square error, even though being important metrics for estimating model errors, are not optimal when assessing model performance at different chemical regimes as found over $\mathrm{Eu}-$ rope.

Based on the evaluation guidelines and previous work within GEMS/MACC (Seigneur et al., 2010; Elguindi et al., 2010; Ordonez et al., 2010; Eskes et al., 2015) we use the 
Modified Normalized Mean Bias (MNMB) as a measure of the bias of modeled versus observed values. This metric treats over- and underprediction in a symmetric manner ranging between -2 and 2 , in contrast to normalized mean bias that can grow to very high values much greater than unit. The MNMB is calculated from Eq. (1) as follows:

$\mathrm{MNMB}=\frac{2}{N} \sum_{i}^{N} \frac{f_{i}-o_{i}}{f_{i}+o_{i}}$

where $f_{i}$ and $o_{i}$ are the mean monthly modeled and observed values, respectively, and $N$ is the sample size. Seasonal averages are calculated as: winter (DJF), spring (MAM), summer (JJA) and autumn (SON).

Furthermore, as a measure of the overall model error we use the Fractional Gross Error (FGE) calculated from Eq. (2), with its values ranging between 0 and 2 . The advantage of this measure is the linear dependence on the departure, which makes this measure less sensitive to outliers and tails in the distribution as compared to the more standard root-mean square.

$\mathrm{FGE}=\frac{2}{N} \sum_{i}^{N}\left|\frac{f_{i}-o_{i}}{f_{i}+o_{i}}\right|$.

The Pearson correlation $(R)$ is used for the quantification of the temporal agreement (interannual variability), between the mean monthly observational and simulated data, where $\sigma_{f}$ and $\sigma_{o}$ in Eq. (3) denote the standard deviation of the modeled and observed values, respectively:

$R=\frac{\frac{1}{N} \sum_{i}\left(f_{i}-\bar{f}\right)\left(o_{i}-\bar{o}\right)}{\sigma_{f} \sigma_{o}}$.

The annual cycle of the diurnal range was calculated from the mean diurnal cycle of each station. The confidence interval for each month was derived using the values of the diurnal range for the stations that reside in the same subregion.

In the following section we present a thorough evaluation of surface ozone covering the years from 2003 to 2012, including the three basic validation metrics, analysis of diurnal/annual cycles and diurnal ranges. Seasonal averages are calculated as: winter (DJF), spring (MAM), summer (JJA) and autumn (SON). Additionally, surface ozone data are discussed along with nitrogen oxides, wherever data allows comparisons, in order to characterize different chemistry regimes above Europe, with respect to photochemical production.
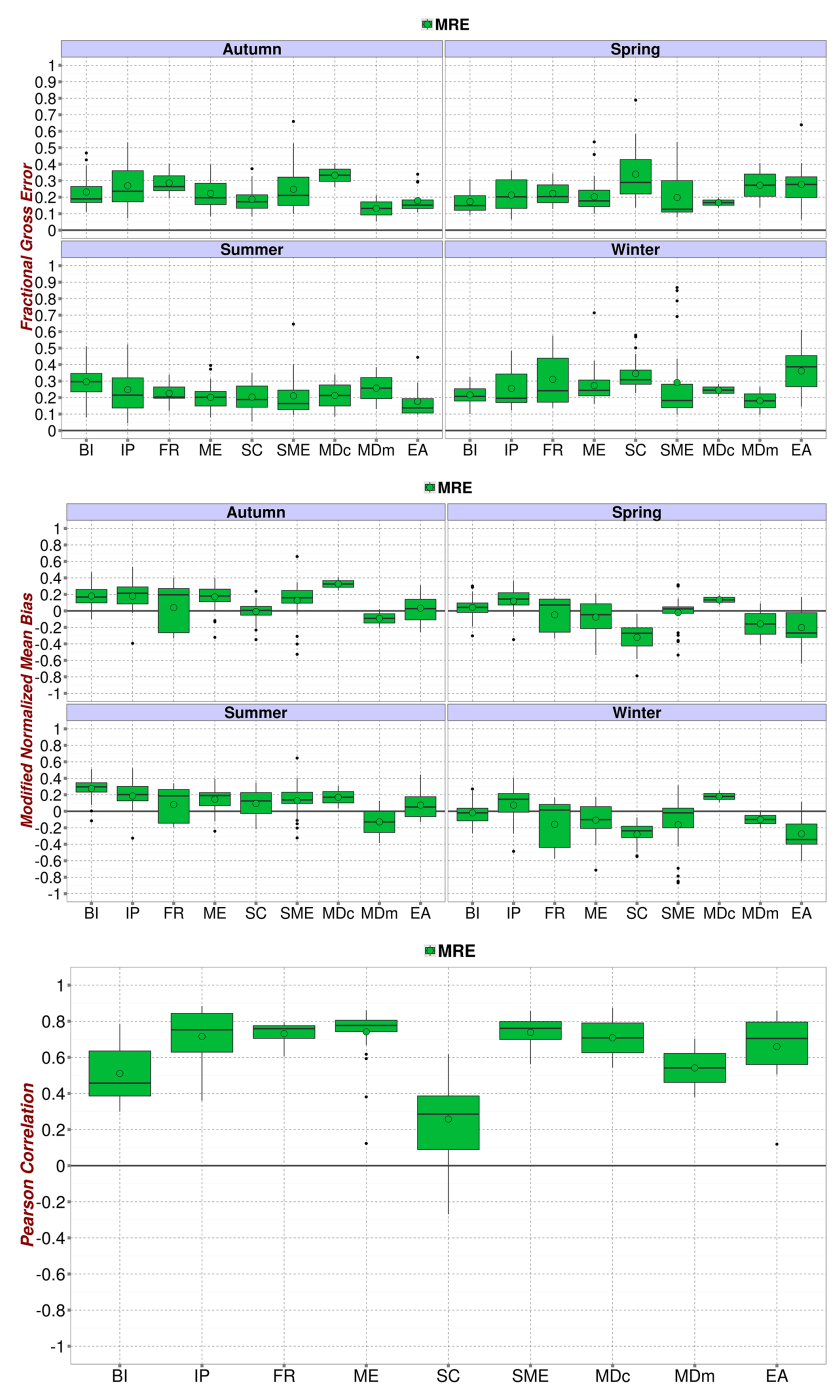

Figure 2. Average 2003-2012 seasonal FGE (top), MNMB (middle) and annual $R$ (bottom) of near-surface ozone for the different European subregions of the MACC reanalysis. The color dots correspond to means. The bottom and top of the box are the first and third quartiles (Q1 or 25th percentile and Q3 or 75th percentile) and the vertical horizontal line in the box is the median $(\mathrm{Q} 2$ or 50th percentile). The colored points on each box indicate the mean value.

\section{Evaluation of the 2003-2012 MACC reanalysis near-surface ozone}

\subsection{Validation metrics}

The annual statistics of surface ozone are shown in Table 2. The FGE for the whole reanalysis period (2003-2012) ranges mostly from $21 \%$ in Mediterranean marine stations to $27 \%$ in Scandinavia. Figure 2 shows the basic validation metrics on a seasonal basis for the MACC reanalysis. The Iberian Peninsula and mid-Europe have a more stable performance with respect to FGE, with an average $20 \%$ for all seasons. All 
Table 2. Annual statistics of near-surface ozone for the MACC reanalysis (2003-2012) over the different European subregions. FGE and MNMB are expressed in \%.

\begin{tabular}{lrrr}
\hline Region & FGE & MNMB & $R$ \\
\hline BI & 23 & 12 & 0.51 \\
IP & 25 & 14 & 0.72 \\
FR & 26 & -2 & 0.73 \\
ME & 22 & 3 & 0.74 \\
SC & 27 & -13 & 0.26 \\
SME & 24 & 2 & 0.74 \\
MD & 24 & 20 & 0.71 \\
MD $_{\mathrm{m}}$ & 21 & -12 & 0.54 \\
EA & 25 & -9 & 0.66 \\
\hline
\end{tabular}

other regions have errors ranging from 10 to $30 \%$ depending on season. A more thorough analysis on the seasonal behavior of surface ozone is provided in the following section.

The seasonal MNMB in Fig. 2 (middle panel) is close to zero for most subregions. The final MRE surface ozone product exhibits its highest MNMB for Scandinavia and East Europe in winter $(-20 \%)$. In summer the MNMB is mostly positive and remains $< \pm 20 \%$ for most sub-regions, with the exception of Britain and Ireland $(+30 \%)$. Transitional season (spring/autumn) biases follow the patterns of the preceding season (winter/summer), since the atmospheric trace gases need some time to adjust from the winter to the summer-time chemistry regime.

Figure 2 (bottom panel) shows the temporal correlation of the 2003-2012 near-surface ozone time series, built upon mean monthly values, and therefore providing a clue on the representation of ozone seasonality. The lowest correlation is found over Scandinavia (0.26), followed by Britain and Ireland (0.51) and the Mediterranean marine stations (0.54). All other regions have correlations $\geq 0.7$.

To investigate the impact of assimilation on near-surface ozone we compare the MRE and CTRL simulations with the observations. Table 3 shows the annual statistics of the MRE and the CTRL simulation. The greatest improvement in the MACC reanalysis because of the assimilation is noted over Scandinavia, where the annual FGE is reduced from 40 to $27 \%$, Eastern Europe (FGE drops from 38 to $25 \%$ ), Mediterranean continental stations (from 43 to $29 \%$ ) and mid-Europe (from 31 to $24 \%$ ). In the same areas the MNMB is also reduced by up to $23 \%$ (SC). In France and the Iberian Peninsula there seems to be a small increase in the FGE (6 and $8 \%$ respectively) and a small change in the MNMB (reduced to zero in FR and increased by $5 \%$ in IP). Over southmiddle Europe and the Mediterranean marine stations the change in FGE and MNMB is negligible on an annual basis.

The temporal correlation of monthly mean time series from 2003 to 2010 is reduced in the MRE, especially over the Mediterranean marine stations (drops from 0.74 to 0.49 )
Table 3. Annual statistics of near-surface ozone for the MACC reanalysis (MRE) and the control run (CTRL) over the different European subregions for the common period from 2003 to 2010. FGE and MNMB are expressed in \%.

\begin{tabular}{lrrrrrrrrr}
\hline \multirow{2}{*}{ Region } & \multicolumn{2}{c}{ FGE } & & \multicolumn{2}{c}{ MNMB } & & \multicolumn{2}{c}{$R$} \\
\cline { 2 - 3 } \cline { 8 - 9 } \cline { 8 - 9 } & MRE & CTRL & & MRE & CTRL & & MRE & CTRL \\
\hline BI & 24 & 22 & & 13 & -7 & & 0.51 & 0.59 \\
IP & 25 & 17 & & 15 & 10 & & 0.70 & 0.79 \\
FR & 28 & 22 & & 0 & -5 & & 0.73 & 0.79 \\
ME & 24 & 31 & & 4 & -17 & & 0.73 & 0.80 \\
SC & 27 & 40 & & -12 & -35 & & 0.23 & 0.39 \\
SME & 25 & 22 & & 3 & -5 & & 0.73 & 0.78 \\
MDc & 29 & 43 & & 26 & 42 & & 0.71 & 0.74 \\
MDm & 21 & 19 & & -10 & -12 & & 0.49 & 0.74 \\
EA & 25 & 38 & & -8 & -28 & & 0.64 & 0.70 \\
\hline
\end{tabular}

and Scandinavia (from 0.39 to 0.23 ). The temporal correlation over Scandinavia is very low, because the MRE cannot capture the spring maximum, as it will be shown in Sect. 3.2. Moreover, the issue of the MLS bias correction in the assimilation procedure has caused drifts in the tropospheric ozone concentrations between August 2004 and December 2007 (a detailed explanation of this issue can be found in Inness et al., 2013). The problem was tracked down and alleviated after year 2008 of the MRE. The deterioration of the temporal correlation in the MRE in comparison to the control simulation can be attributed to the assimilation procedure followed up to MRE year 2008. Calculation of temporal correlation coefficients before (2003-2007) and after (2008-2012) indicates that $\mathrm{R}$ increases in all subregions after removal of MLS bias correction. Figure 3 shows the comparison of the seasonal FGE, MNMB and R for the MRE and the CTRL near surface ozone over the different European subregions for the common time period 2003-2010. On a seasonal basis the greatest improvement due to assimilation is seen during the winter months, when the CTRL suffers from the largest negative bias. The impact on surface ozone is smaller in summer, eventually because near-surface ozone is largely controlled by photochemical processes.

\subsection{Annual cycle of near-surface ozone}

The average 2003-2012 observed and MRE annual cycle of near-surface ozone is shown in Fig. 4. With the only exception of the Mediterranean region (MDc and MDm), the modeled annual cycles of ozone have differences in the shape from the observed ones. The most striking disagreement is seen over Scandinavia (SC), where the MRE captures the annual range (13 ppb: the monthly maximum minus the monthly minimum of the year), but completely fails to reproduce surface ozone seasonality. While observations indicate a clear spring maximum ( $40 \mathrm{ppb}$ ), a characteristic ozone behavior in very clean and remote atmospheres in the Northern Hemisphere (Volz and Kley, 1988), no indication of spring 

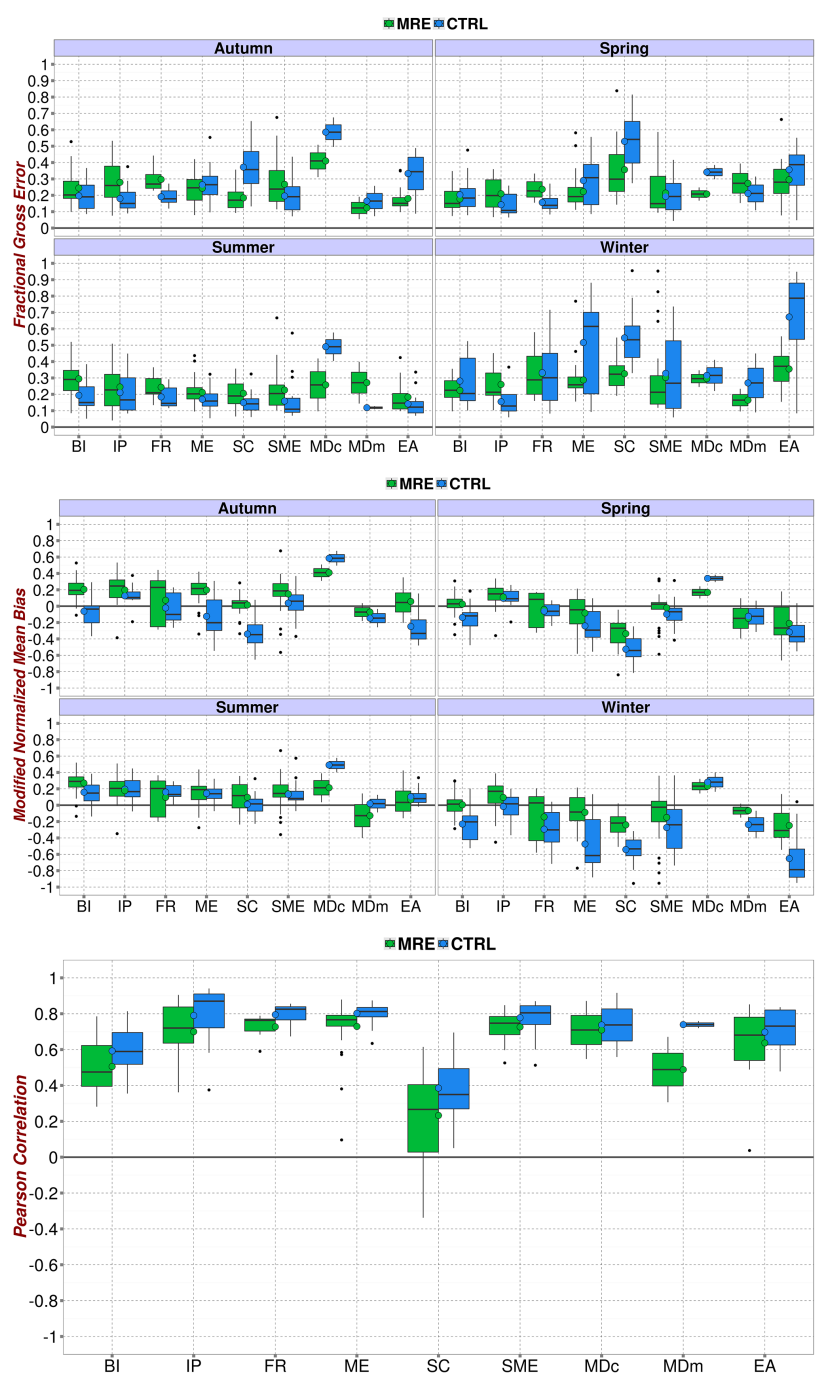

Figure 3. Average 2003-2010 seasonal FGE (top), MNMB (middle) and annual $R$ (bottom) of near-surface ozone for the different European subregions of the MACC reanalysis (green) and the control run (blue).

ozone maximum is evident in the MRE surface ozone; on the contrary, a clear lower maximum ( $35 \mathrm{ppb})$ is found in late summer.

Over Britain and Ireland (BI) we also note striking differences in the shape of the annual cycle. Specifically, there is disagreement (a) in the timeliness of the early spring maximum, which is seen in April for observed ozone and the late spring-early summer for the MRE, and (b) in the annual ozone range, which is overestimated by about $7 \mathrm{ppb}$. The overestimation occurs mainly during the summer/autumn season. We should note that, even though the MRE nearsurface ozone at SC and BI does not capture the observed spring maximum peaking in April, this spring ozone maximum is better seen in the lower free troposphere at 850 and $700 \mathrm{hPa}$ vertical levels of MRE (not shown here).

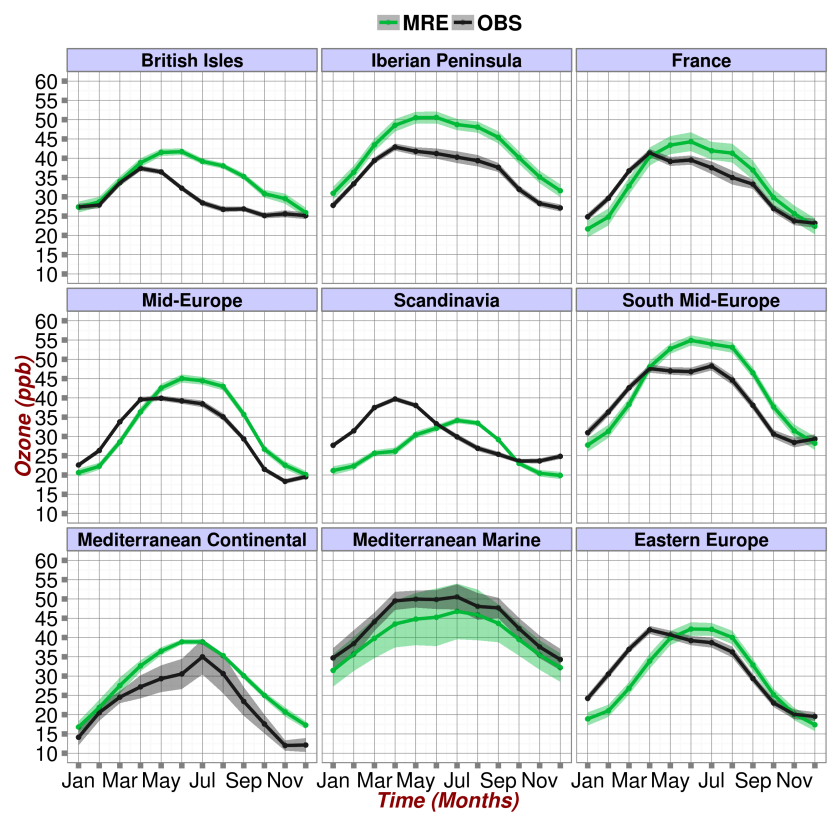

Figure 4. Mean 2003-2012 annual cycle of near-surface ozone for the different European subregions of the MACC reanalysis and observations. The shading areas denote $95 \%$ confidence interval of the mean values.

In mid-Europe (ME), the observational broad springsummer maximum (April-July) is captured by the MRE, with a month's time-lag (May to August) causing an underestimation in MRE of 2-3 ppbv from January to April and an overestimation from May to November (Fig. 4). The highest overestimation (ranging from 5 to $9 \mathrm{ppbv}$ ) in MRE is seen during the warm months from June to September. This behavior results in an overestimated annual amplitude in MRE in comparison to observations.

Over the Iberian Peninsula (IP) there is an agreement in the seasonal cycle of MRE near-surface ozone with observations, with a broad spring-summer maximum but MRE misses the April peak shown in observations. The amplitude of the MRE annual cycle is also overestimated by roughly 4 ppbv in comparison to observations, mostly stemming from the MRE summer $\mathrm{O}_{3}$ overestimation, with the MRE June-maximum reaching up to $50 \mathrm{ppbv}$, while the observed to $40 \mathrm{ppbv}$. We should also take into consideration that the seasonal cycle of MRE at $700 \mathrm{hPa}$ shows a broad spring-summer maximum with a peak in April as in near-surface observations (discussed in Sect. 4.1).

A similar pattern of differences between MRE and observations are found for France (FR), south-middle Europe (SME) and Eastern Europe (EA) although over EA the differences are smaller.

Overall, the annual cycles of the observed data reflect the specific subregional characteristics, namely the broad springsummer maximum at Mediterranean (MDc and MDm) and south-middle Europe (SME), the broad spring-summer max- 
imum peaking in April at Eastern Europe (EA), mid-Europe (ME), France (FR) and Iberian Peninsula (IP) and the early spring maximum over northern latitudes at Scandinavia (SC) and Britain and Ireland (BI). MRE near-surface ozone reproduces fairly well the photochemically driven broad springsummer maximum of surface ozone of the sub-regions at central and south Europe, however, fails to capture the early spring peak in most of these subregions. This shortfall of MRE to capture the early spring peak has also been noted by Inness et al. (2013) and it is further discussed in the following sections. Furthermore, there is generally a tendency for overestimating the annual amplitude in MRE in comparison to observations.

Factors improving ozone seasonality could be emission strengths and temporal profiles and dry deposition (Val Martin et al., 2014). Ongoing work on the impact of dry deposition on surface ozone indicates that the new on-line dry depositions schemes currently tested in the C-IFS system improve the surface ozone positive bias, appearing mostly over southern Europe in summer, but cannot completely tackle the spring ozone maximum problem over northern Europe (J. Flemming, personal communication, 2015).

\subsection{Diurnal cycle of near-surface ozone}

Figure 5 depicts the mean 2003-2012 diurnal cycle of nearsurface ozone for each season for the selected European regions. All diurnal cycles have the expected behavior with sharply increasing ozone concentrations during the daytime hours (from 05:00-06:00 UTC in summer and 1-2 $\mathrm{h}$ later in winter to 15:00-16:00 UTC) and decreasing afterwards. The diurnal cycles are more pronounced in the summer season and south Europe due to the more intense photochemistry. The MRE reproduces the diurnal cycle but exhibits positive bias in summer (except for the Mediterranean marine region), which may be persisting during the whole day (BI, SME, $\mathrm{IP}, \mathrm{ME}$ ) or occur mostly during daytime (EA, FR, MDc). In winter there is a small negative bias in all regions, except for MDc (positive bias) and BI (zero bias). The transitional seasons have diurnal cycles that share both winter and summertime characteristics: the spring diurnal bias resembles winter with respect to bias, but has the enhanced photochemical diurnal cycle of summer, though not fully developed.

Figure 6 shows the annual cycle of the diurnal range of near-surface ozone over the different European subregions. The diurnal range of ozone is a good indication of the potential for the local diurnal ozone build up through photochemical production processes (Zanis et al., 2000). There is generally a good agreement with observations, suggesting that MRE reproduces adequately the observed diurnal ozone range with a tendency for a small overestimation during the warm months for the subregions of central and southern Europe. More specifically, over SME, FR and MDc the diurnal range is overestimated during the whole year but, to a lesser extent in colder months, while over EA, ME, BI and SC the

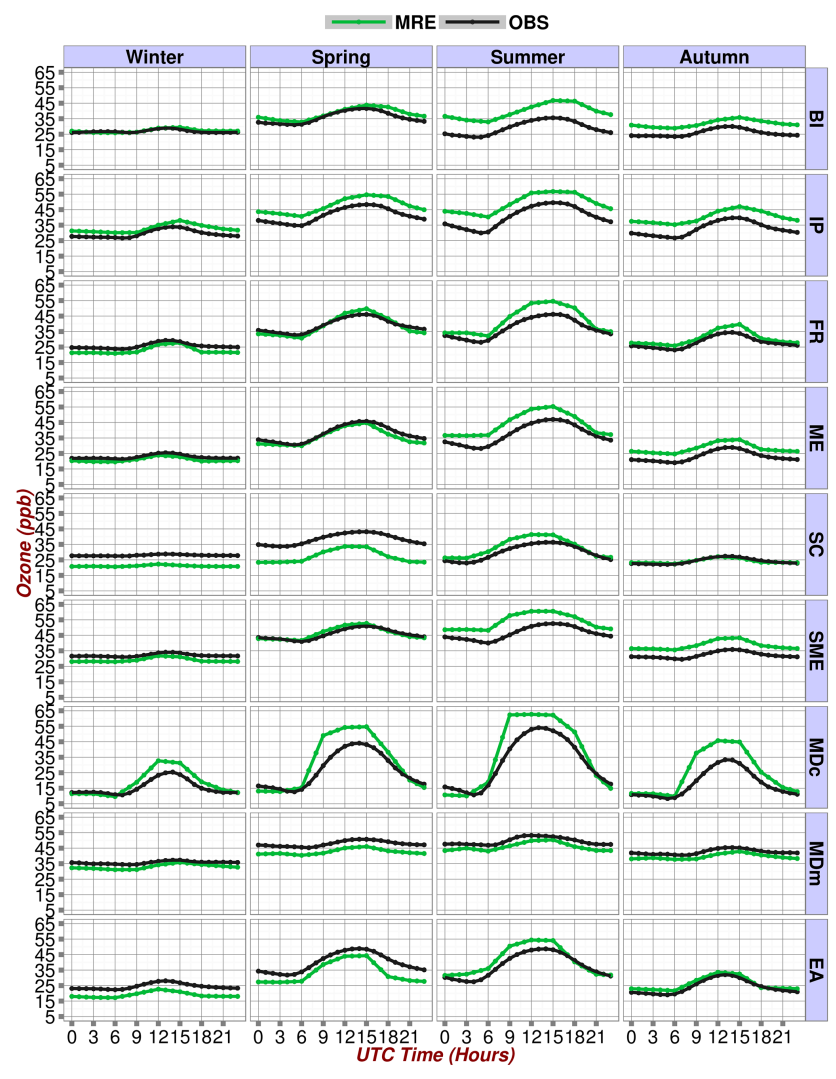

Figure 5. Mean 2003-2012 diurnal cycle of near-surface ozone for the different European subregions based on MRE (green line) and observations (black line) calculated for winter (DJF), spring (MAM), summer (JJA) and autumn (SON).

overestimation is smaller and restricted during the summer. Hence the diurnal range is overestimated more at the southern regions (SME, FR and MDc) than at the northern regions (EA, ME, BI and SC) and more during the warm months than during the cold months.

\section{Discussion}

In this section we discuss possible reasons for the differences revealed in the shape of the annual cycle of nearsurface ozone between observations and MRE and the failure in MRE to capture the early spring peak in most of the subregions. We discuss possible contributions from the abovementioned processes based on the comparison of MRE ozone profiles with available ozonesonde measurements, as well as on $\mathrm{NO}_{x}$ versus $\mathrm{O}_{3}$ annual and diurnal cycles.

\subsection{Ozone profiles}

Comparison with ozonesonde measurements at different locations (Fig. 7) indicate that MRE ozone profiles reproduce the basic structure of the profile, overestimating in most cases ozone below the $850 \mathrm{hPa}$. We note positive and negative bi- 


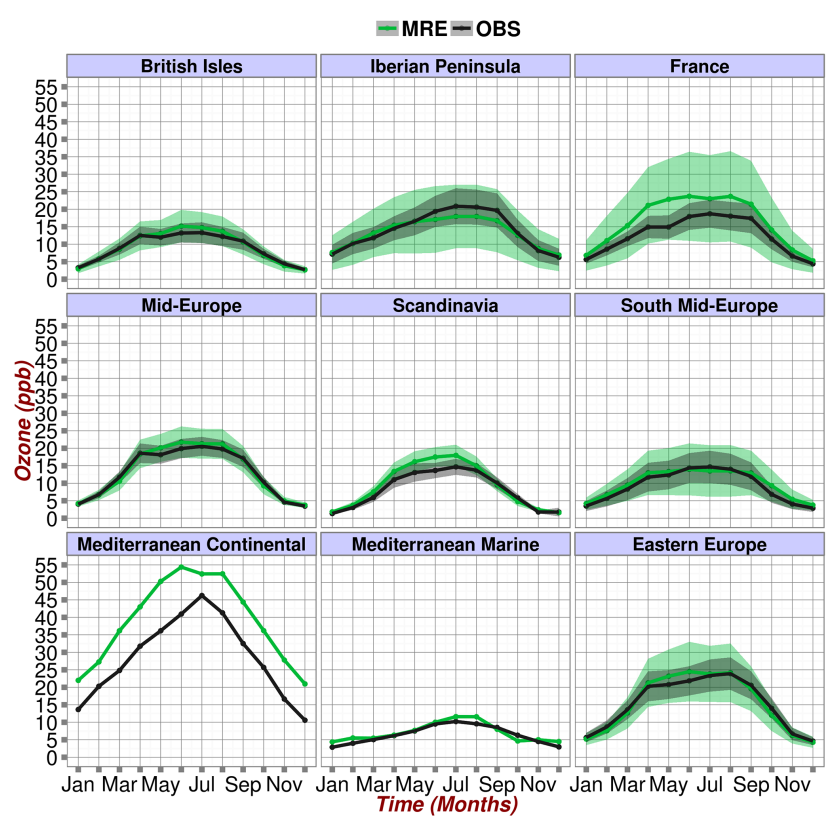

Figure 6. Annual cycle of the diurnal range of near-surface ozone for observations (black line) and MRE (green line) averaged over the time period 2003-2012 for the different European subregions. Shading areas denote the $95 \%$ confidence interval of the mean values. The $95 \%$ confidence interval is not displayed for the Mediterranean subregions, which consist of a limited number of stations.

ases depending on the location and the altitude, but there is a tendency for a larger positive bias during summer and autumn for most locations below $850 \mathrm{hPa}$, while the $\%$ biases in the middle and upper troposphere are generally smaller. This is in agreement with the study of Inness et al. (2013), who, analyzing MACC reanalysis over the time period 20032010 , reported a negative bias with respect to ozonesondes above $650 \mathrm{hPa}$ and the largest positive bias below $800 \mathrm{hPa}$. It should also be considered that the range of the \% biases in the troposphere are comparable with the respective precision of electrochemical concentration cell ozonesonde measurements.

Furthermore, the shape of the observed ozone annual cycle (based on the ozonesondes) in lower free troposphere at $700 \mathrm{hPa}$ is reproduced rather well by the MRE (Fig. 8). The course of the annual cycle is also reproduced for the middle troposphere at $500 \mathrm{hPa}$ (not shown here). Despite the biases, the reasonable reproduction of the shape of the observed ozone seasonal cycle by MRE in the middle and lower free troposphere is consistent with transport processes from the lower stratosphere and the upper troposphere as well as long-range transport being resolved adequately by the MRE.

\section{2 $\mathrm{NO}_{x}$ versus $\mathrm{O}_{3}$ annual and diurnal cycles}

According to the analysis of ozone profiles (see Sect. 4.1) we may assume that assimilation in MRE leads to a reasonable
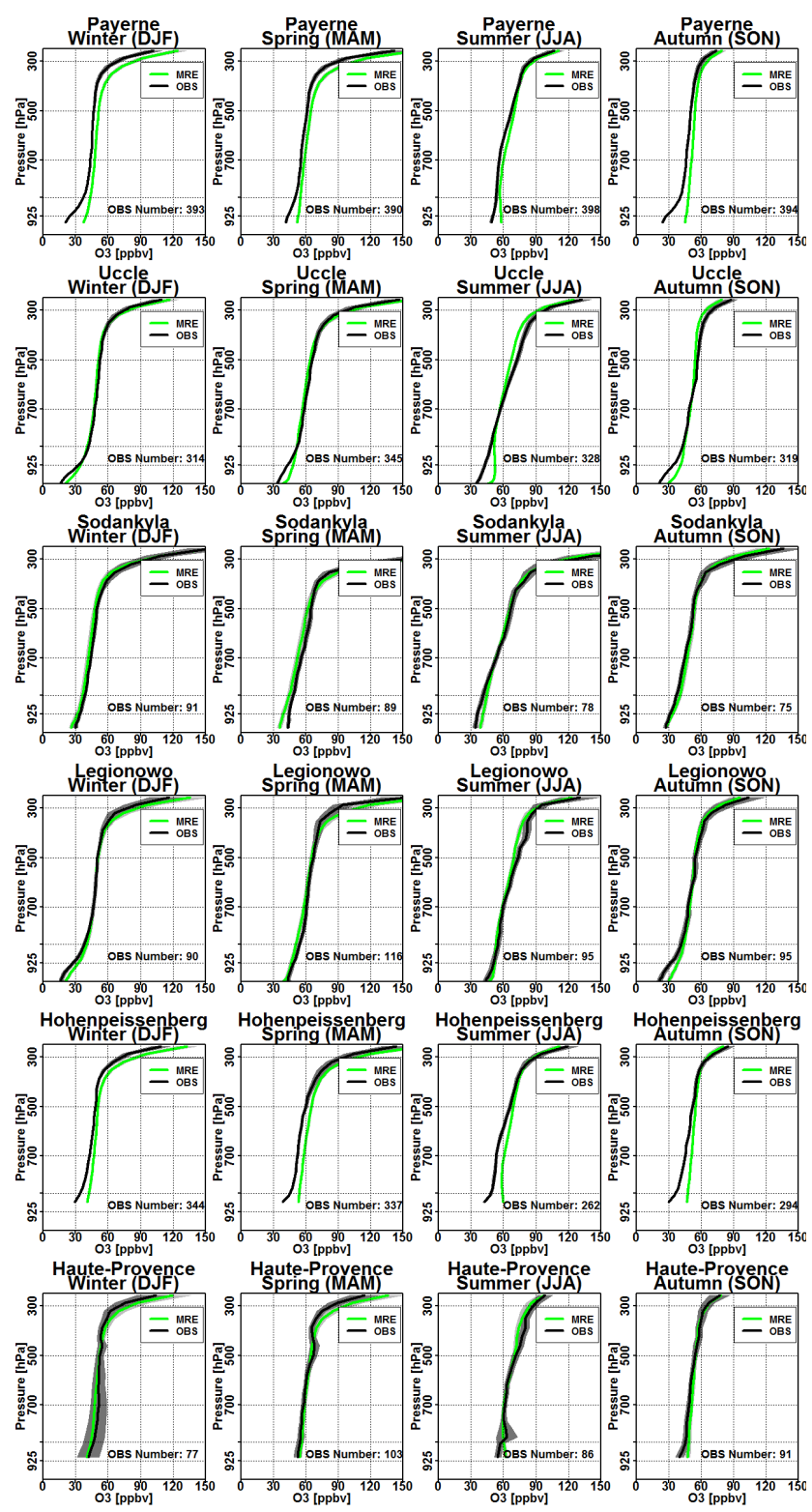

Figure 7. Mean 2003-2012 ozone profiles based on MRE nearsurface ozone (green line) and ozonesonde measurements (black line) at the stations of Sodankyla $\left(67.4^{\circ} \mathrm{N}, 26.6^{\circ} \mathrm{E}\right)$, Legionowo $\left(52.4^{\circ} \mathrm{N}, 20.9^{\circ} \mathrm{E}\right)$, Uccle $\left(50.8^{\circ} \mathrm{N}, 4.3^{\circ} \mathrm{E}\right)$, Hohenpeissenberg $\left(47.8^{\circ} \mathrm{N}, 11^{\circ} \mathrm{E}\right)$, Payerne $\left(46.8^{\circ} \mathrm{N}, 6.9^{\circ} \mathrm{E}\right)$, and Haute-Provence $\left(43.9^{\circ} \mathrm{N}, 5.7^{\circ} \mathrm{E}\right)$. The shading areas denote $95 \%$ confidence interval of the mean values.

representation of the ozone annual cycles at the middle and upper troposphere, thus mediating for a realistic contribution of STT. Hence, it could be speculated that differences in the shape of the seasonal cycle of near-surface ozone between observations and the MRE could be also linked to the potential of photochemical ozone production and the strength of the exchange between the lower free troposphere and the atmospheric boundary layer (ABL). Two tentative explana- 

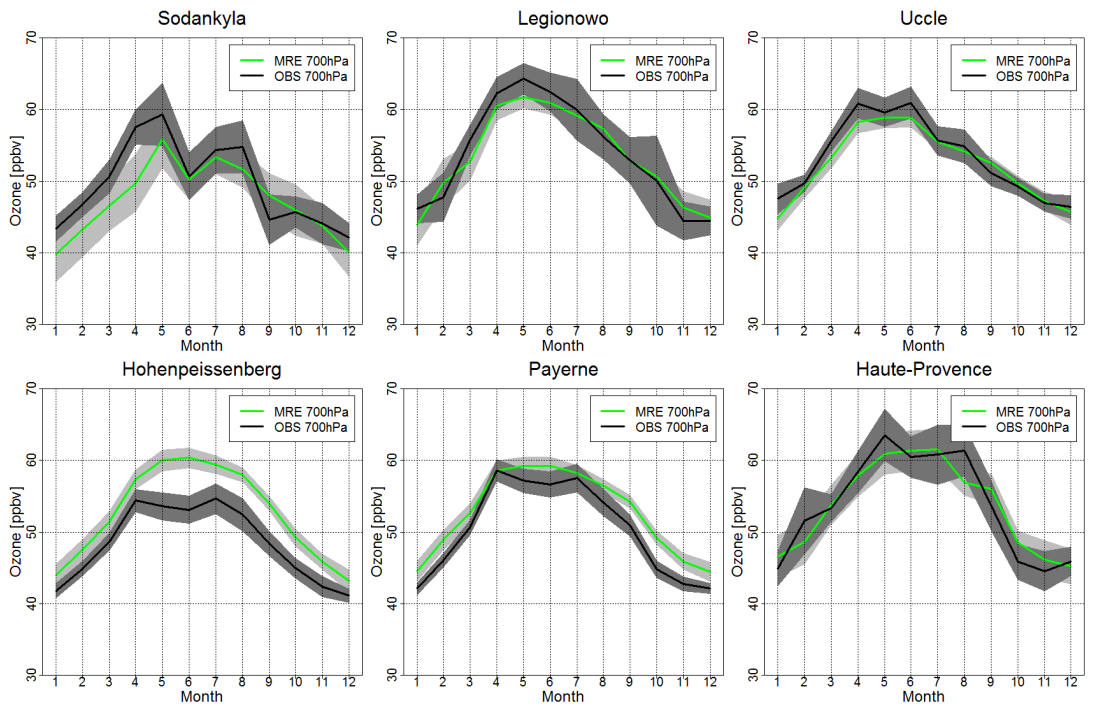

Figure 8. Mean 2003-2012 annual cycle of lower tropospheric ozone at $700 \mathrm{hPa}$ based on MRE (green line) and ozonesonde measurements (black line) at the stations of Sodankyla $\left(67.4^{\circ} \mathrm{N}, 26.6^{\circ} \mathrm{E}\right)$, Legionowo $\left(52.4^{\circ} \mathrm{N}, 20.9^{\circ} \mathrm{E}\right)$, Uccle $\left(50.8^{\circ} \mathrm{N}, 4.3^{\circ} \mathrm{E}\right), \mathrm{Hohenpeissenberg}^{\circ}$ $\left(47.8^{\circ} \mathrm{N}, 11^{\circ} \mathrm{E}\right)$, Payerne $\left(46.8^{\circ} \mathrm{N}, 6.9^{\circ} \mathrm{E}\right)$, and Haute-Provence $\left(43.9^{\circ} \mathrm{N}, 5.7^{\circ} \mathrm{E}\right)$. The shading areas denote $95 \%$ confidence interval of the mean values.

tions could be provided on the mismatch between model and observations: (a) inadequate seasonality/emission strengths in surface emissions of precursor species (some issues discussed in Stein et al., 2014) and (b) a loose coupling of the free troposphere to the $\mathrm{ABL}$, which would be responsible for the entrainment of the assimilated free tropospheric $\mathrm{O}_{3}$ into the ABL.

In global scales nitrogen oxides $\left(\mathrm{NO}_{x}\right)$ are the limiting precursors for $\mathrm{O}_{3}$ production throughout most of the troposphere, and also directly influence the abundance of the hydroxyl radical concentration in the troposphere (e.g. Crutzen, 1988). At regional scale for rural environments with $\mathrm{NO}_{x}$ values less than a few parts per billion by volume, $\mathrm{O}_{3}$ formation is $\mathrm{NO}_{x}$ limited (Liu et al., 1987) and therefore almost independent of hydrocarbon concentrations, depending of course on the ratio of reactivity-weighted VOC mixture to $\mathrm{NO}_{x}$, which may differ from region to region across $\mathrm{Eu}-$ rope (Beekmann and Vautard, 2010). Emissions of $\mathrm{NO}_{x}$ occur primarily as $\mathrm{NO}$, followed by oxidation to $\mathrm{NO}_{2}$ while $\mathrm{O}_{3}$ is photochemically produced as $\mathrm{NO}_{x}$ are consumed in favor of their atmospheric oxidation products $\mathrm{NO}_{z}$ (Liu et al., 1987; Zanis et al., 2007). $\mathrm{NO}_{z}$ comprises mostly of peroxyacetyl nitrate (PAN) and nitric acid $\left(\mathrm{HNO}_{3}\right)$, along with $\mathrm{HNO}_{4}, \mathrm{~N}_{2} \mathrm{O}_{5}, \mathrm{NO}_{3}$ and other Acyl-peroxy nitrates (APNs) and organic nitrates (Emmons et al., 1997). The lifetime of $\mathrm{NO}_{x}$ before photochemical conversion to $\mathrm{NO}_{z}$ is less than a day in summer at mid-latitudes (Logan, 1983).

Here, in order to assess the potential of the photochemical ozone production related to $\mathrm{NO}_{x}$ emissions, we have looked at the annual cycle of $\mathrm{NO}_{x}$ versus the respective annual cycle of $\mathrm{O}_{3}$, as well as the summertime diurnal cycle of $\mathrm{O}_{3}$ along with the diurnal cycle of $\mathrm{NO}_{x}$ at the different sub-regions of our domain. As mentioned in Sect. 2.2, after our stationfiltering, only three sub-regions remained, with a considerable number of stations having both $\mathrm{O}_{3}$ and $\mathrm{NO}_{x}$ measurements; Britain and Ireland (BI), Iberian Peninsula (IP) and mid-Europe (ME).

Figure 9 shows the annual cycle of $\mathrm{O}_{3}$ and $\mathrm{NO}_{x}$ for $\mathrm{BI}$, IP and ME. At the BI the $\mathrm{NO}_{x}$ levels are overestimated in MRE throughout the year by up to 2 ppbv in comparison to the observations while ozone is overestimated from May to November. The overestimation of $\mathrm{NO}_{x}$ concentrations at BI may partially account for the positive ozone bias during the warm period of the year, through overestimated photochemical ozone production. At IP and ME, $\mathrm{NO}_{x}$ levels are systematically underestimated in MRE throughout the year, and still ozone is overestimated in MRE - especially during the warm part of the year - despite the $\mathrm{NO}_{x}$ underestimation.

Figure 10 shows the average diurnal cycle of $\mathrm{O}_{3}$ and $\mathrm{NO}_{x}$ during summer for BI, IP and ME. Discarding any biases in the level of $\mathrm{O}_{3}$ and $\mathrm{NO}_{x}$ concentrations, it is shown that $\mathrm{O}_{3}$ builds up during the daytime, while $\mathrm{NO}_{x}$ is consumed in both MRE and observations. This daytime $\mathrm{NO}_{x}$ decrease can be attributed to chemical loss through oxidation to $\mathrm{NO}_{z}$. Nevertheless, diurnal meteorological patterns of wind speed and boundary layer height, that lead to higher dilution of primary pollutants at daytime rather than at nighttime, may also contribute to the diurnal pattern of $\mathrm{NO}_{x}$ in Fig. 10 (see Fig S1 in the Supplement). This is supported by the fact that $\mathrm{CO}$ in MRE, which is a species with a much longer chemical lifetime than $\mathrm{NO}_{x}$, has a similar diurnal pattern with $\mathrm{NO}_{x}$. 

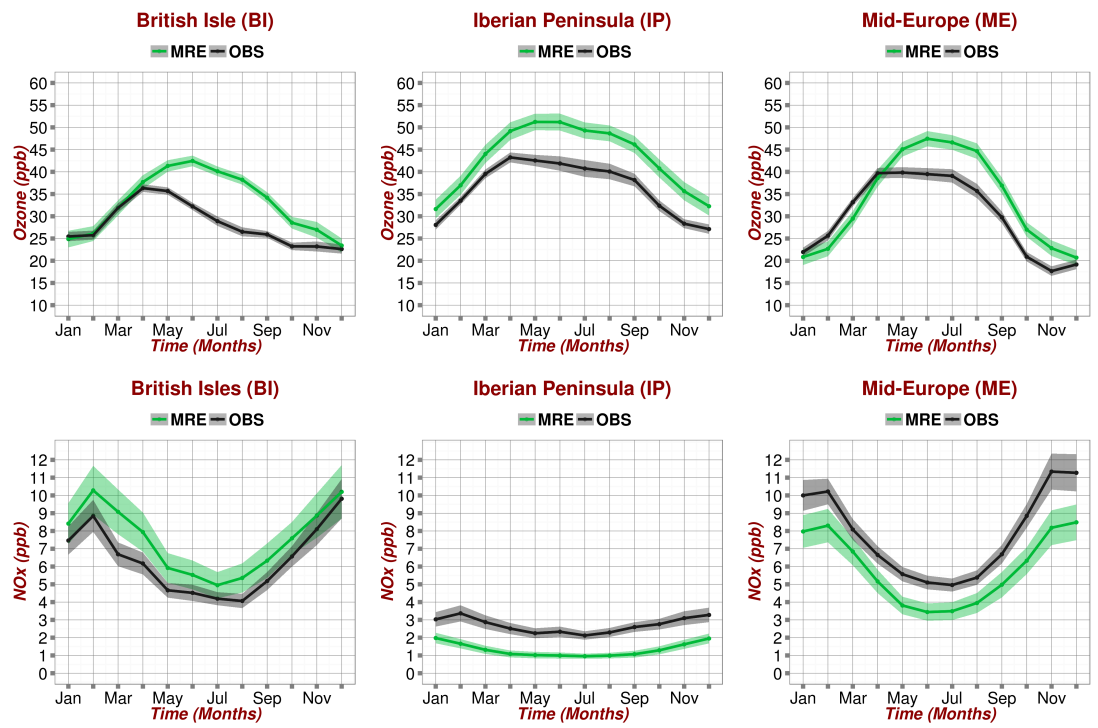

Figure 9. Mean annual cycle of near-surface $\mathrm{O}_{3}$ (top panel) and $\mathrm{NO}_{x}$ (bottom panel) based on observations (solid black line) and MRE (green line) for the subregions BI, IP, ME over the period 2003-2012.

Based on the diurnal amplitudes of $\mathrm{O}_{3}\left(\Delta \mathrm{O}_{3}\right.$ increased over the day) and $\mathrm{NO}_{x}\left(\Delta \mathrm{NO}_{x}\right.$ decreased over the day) shown in Fig. 10, we have calculated the ratio $\Delta \mathrm{O}_{3} / \Delta \mathrm{NO}_{x}$ values for both MRE and observations. The $\Delta \mathrm{O}_{3} / \Delta \mathrm{NO}_{x}$ ratio values for near surface based on MRE are estimated roughly to 3 for $\mathrm{BI}, 3.5$ for $\mathrm{ME}$ and 10 for IP. The respective $\Delta \mathrm{O}_{3} / \Delta \mathrm{NO}_{x}$ values based on the observed diurnal amplitudes are roughly 10 for BI, 6 for ME and 10 for IP. Additionally, we have also estimated $\Delta \mathrm{O}_{3} / \Delta \mathrm{NO}_{x}$ ratio values based on MRE at $925 \mathrm{hPa}$ (above near surface but within the atmospheric boundary layer) being roughly 3.5 for $\mathrm{BI}, 3$ for $\mathrm{ME}$ and 4 for IP. These ratio values reflect the ozone production efficiency, if we assume that daytime $\mathrm{NO}_{x}$ loss is through oxidation to $\mathrm{NO}_{z}$. In order to compare these $\Delta \mathrm{O}_{3} / \Delta \mathrm{NO}_{x}$ ratio values with theoretical calculations of ozone production efficiency, a zero dimension box model with the CBIV chemical mechanism was implemented to calculate ozone production efficiencies for typical summer conditions using initial conditions for $\mathrm{NO}_{x}$ and other gaseous species from MRE at BI, IP and ME. These box model calculations indicated that 3 to 4 molecules of $\mathrm{O}_{3}$ produced for every molecule of $\mathrm{NO}_{x}$ oxidised at $\mathrm{BI}$ and $\mathrm{ME}$ and up to 5 at IP. The above values agree well with ozone production efficiency estimates from previous studies for summer at rural semi-polluted sites with $\mathrm{NO}_{x}$ more than a few ppbv in Europe and US (Chin et al., 1994; Derwent and Davis, 1994; Rickard et al., 2002). The $\Delta \mathrm{O}_{3} / \Delta \mathrm{NO}_{x}$ ratio values based on MRE are comparable with the box model calculated ozone production efficiency values.

The amplitude of the diurnal cycle of $\mathrm{NO}_{x}$ is much stronger in the MRE than at observations for BI and ME, which indicates that in MRE we presumably have a more intense local oxidation from $\mathrm{NO}_{x}$ to $\mathrm{NO}_{z}$. This more intense local oxidation from $\mathrm{NO}_{x}$ to $\mathrm{NO}_{z}$ at $\mathrm{BI}$ and $\mathrm{ME}$ can lead to higher local photochemical ozone production, which may account for the slightly higher amplitude of the diurnal cycle of $\mathrm{O}_{3}$ for the MRE than the observations (by roughly $2 \mathrm{pppv}$ at $\mathrm{BI}$ and $1 \mathrm{ppbv}$ at ME) and partially for the generally higher $\mathrm{O}_{3}$ levels of the MRE compared to the observed. The differences in local photochemical ozone production at BI and ME versus IP are consistent with the chemical regime indicator analysis for near-surface ozone over Europe by Beekmann and Vautard (2010), who defined three particular regions: (a) the region in north-western Europe with a pronounced VOC sensitive regime $\left(1^{\circ} \mathrm{W}-6^{\circ} \mathrm{E}\right.$, $\left.50-53^{\circ} \mathrm{N}\right)$, (b) the Mediterranean region $\left(6^{\circ} \mathrm{W}-20^{\circ} \mathrm{E}, 38-\right.$ $43^{\circ} \mathrm{N}$ ) with an average $\mathrm{NO}_{x}$ sensitive chemical regime and c) north-eastern Germany $\left(9-14^{\circ} \mathrm{E}, 50-54^{\circ} \mathrm{N}\right)$ which is a transition region between both regimes. Comparing this chemical regime analysis with our selected sub-regions BI, ME and IP, we note that $\mathrm{BI}$ and ME sub-regions are a mixture of a VOC sensitive regime and an $\mathrm{NO}_{x}$ sensitive regime, while IP is a $\mathrm{NO}_{x}$ sensitive regime.

In the case of IP, the amplitude of the diurnal cycle of $\mathrm{NO}_{x}$ is similar for both observations and MRE, while the amplitude of the diurnal cycle of $\mathrm{O}_{3}$ is slightly underestimated in the MRE, indicating that local photochemical ozone production is captured adequately or slightly underestimated. Nevertheless, the ozone levels are generally overestimated for the MRE, implying other processes than local photochemistry as a reason for the positive bias. 

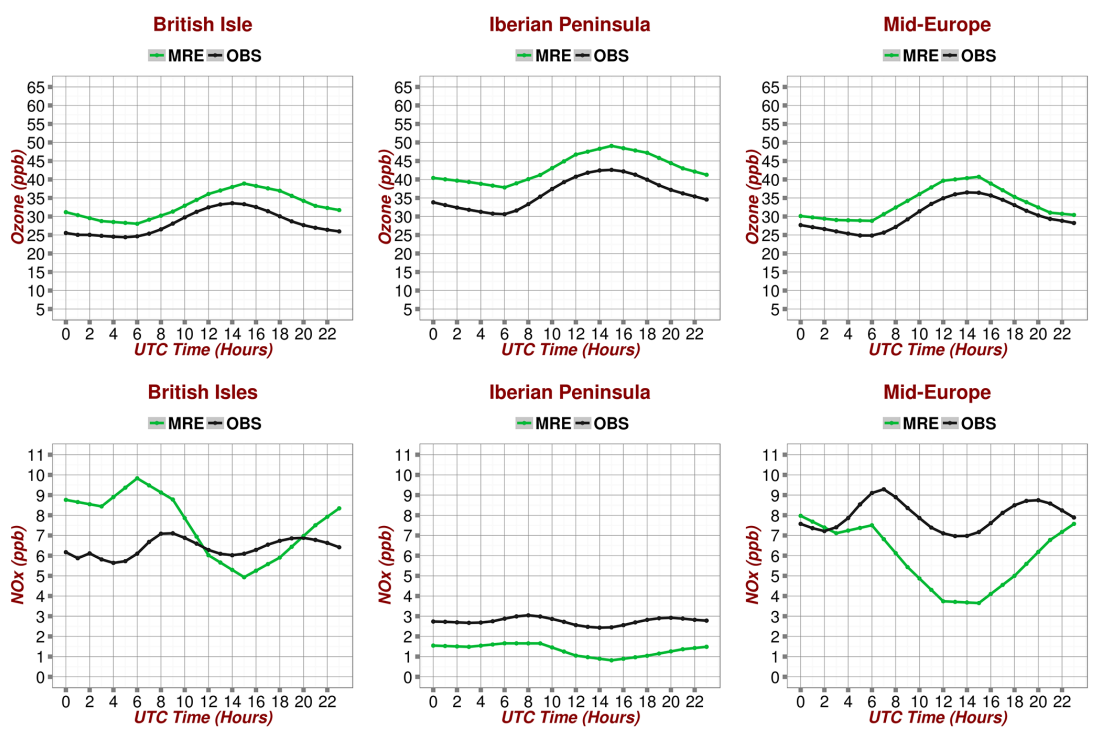

Figure 10. Mean diurnal cycle of near-surface $\mathrm{O}_{3}$ (top panel) and $\mathrm{NO}_{x}$ (bottom panel) based on observations (solid black line) and MRE (green line) for the subregions BI, IP, ME during summer over the period 2003-2012.

\section{Summary and conclusions}

In the current work we evaluate the MACC-II reanalysis (MRE) near-surface ozone for the time period 2003-2012 using rural stations of the EMEP and AirBase monitoring networks. Overall, the evaluation of MRE near-surface ozone with station based observations shows a negative bias in winter over northern Europe and generally positive bias during warm months. With respect to the seasonal cycle, MRE reproduces the photochemically driven broad spring-summer maximum of near-surface ozone at central and south Europe. However, it does not adequately capture the shape of the seasonality with a characteristic early spring maximum at northern and north-eastern Europe. The diurnal range of surface ozone, which is an indication of the local photochemical production processes, is reproduced fairly well in the MACC reanalysis, with a tendency for a small overestimation during the warm months for the subregions of central and south Europe. Comparison of MRE ozone profiles with ozonesonde profiles revealed reasonable reproduction of the shape of the observed ozone seasonal cycle in the middle and lower free troposphere, despite the biases. This suggests that transport processes from the lower stratosphere and the upper troposphere are resolved acceptably by MRE with the aid of the assimilation.

More specifically, the characteristics of near-surface ozone in the MACC reanalysis 2003-2012 can be summarized as follows for the different sub-regions:

a. At Britain and Ireland and Scandinavia, the observed near-surface spring ozone maximum peaking in April is not reproduced by MRE. However, this spring ozone maximum is better seen in the lower free troposphere (at 850 and $700 \mathrm{hPa}$ ) implying adequate vertical transport within the free troposphere, as was also indicated by the good comparison with ozonesonde data. The possibility of insufficient entrainment and mixing from the lower free troposphere into the atmospheric boundary layer should be further investigated. MRE diurnal range of near-surface ozone compares relatively well with the observed diurnal range with a slight overestimation during summer. Analysis of the average MRE diurnal cycle of $\mathrm{O}_{3}$ versus $\mathrm{NO}_{x}$ during summer for the $\mathrm{BI}$ could possibly indicate, among other reasons, more intense local oxidation from $\mathrm{NO}_{x}$ to $\mathrm{NO}_{z}$ than the observed and a systematic positive bias in $\mathrm{NO}_{x}$ which can lead to higher local photochemical ozone production.

b. The ozone summer maximum of the Mediterranean area is captured by the MRE, with a slight overestimation during summer and autumn for the continental stations (MDc). The MRE near-surface ozone diurnal range compares well with the observed one throughout the year for the marine stations (MDm) and is slightly overestimated during the warm months for the continental stations (MDc). This implies that part of the MRE overestimation of near surface in summer and autumn for MDc may be associated with an overestimation of local photochemical production. Zanis et al. (2014) also noted for the Mediterranean an overestimation of near-surface ozone during summer by another global chemistry-climate model, due to overestimated photochemical ozone production within the atmospheric boundary layer. 
c. In Eastern Europe, mid-Europe, south-mid Europe and France, MRE near-surface ozone reproduces the photochemically driven broad spring-summer maximum, but fails to capture the early spring peak in April. Furthermore, there is a slight shift of the seasonal cycle towards summer in MRE compared to observations, with a tendency for an underestimation of ozone levels in cold months (from January to April) and an overestimation in summer and autumn. The diurnal range of near-surface ozone in the MRE is overestimated during summer. This maybe implies an overestimated local photochemical ozone production, which can partially account for the summer overestimated MRE near surface ozone levels (similarly to $\mathrm{MDc}$ ). Further analysis of the average diurnal cycle of $\mathrm{O}_{3}$ versus $\mathrm{NO}_{x}$ during summer for MidEurope, gives some indication for more intense local oxidation from $\mathrm{NO}_{x}$ to $\mathrm{NO}_{z}$ for the MRE than the observations, which can lead to higher local photochemical ozone production despite the systematic negative bias in $\mathrm{NO}_{x}$.

d. At the Iberian Peninsula there is a positive bias throughout the year and the MRE does not capture the April peak shown in the observed seasonal cycle. The MRE diurnal range compares relatively well with the observed diurnal range, maybe indicating that local photochemical production is captured adequately throughout the year. This is also supported from the analysis of the average diurnal cycle of $\mathrm{O}_{3}$ versus $\mathrm{NO}_{x}$ during summer. The seasonal cycle of MRE at $700 \mathrm{hPa}$ shows a broad spring-summer maximum with a peak in April as in near-surface observations. This feature could possibly indicate a loose coupling of the free troposphere with atmospheric boundary layer.

Our analysis suggests that in order to understand better the behavior of near-surface ozone, further analysis is needed for firm conclusions, including model diagnostics for photochemical production and loss terms, as well as the mixing between $\mathrm{ABL}$ and free troposphere. Improvement in the dry-deposition scheme - which is fixed in the current implementation - would also contribute to improvement of model performance (bias/seasonality) with respect to near-surface ozone.

\section{The Supplement related to this article is available online at doi:10.5194/gmd-8-2299-2015-supplement.}

Acknowledgements. MACC II is funded by the European Union's Seventh Framework Programme (FP7) under Grant Agreement no. 283576. We thank the European Environmental Agency (AirBase) and the European Monitoring and Evaluation Programme
(EMEP) for providing access to European $\mathrm{O}_{3}$ and $\mathrm{NO}_{x}$ observations. MACC-III was funded by the European Commission under Horizon2020 as a Coordination \& Support Action, grant agreement number 633080.

Edited by: A. Archibald

\section{References}

Akritidis D., Zanis, P., Pytharoulis, I., and Karacostas, Th.: Nearsurface ozone trends over Europe in RegCM3/CAMx simulations for the time period 1996-2006, Atmos. Environ., 97, 6-18, 2014.

Baertsch-Ritter, N., Keller, J., Dommen, J., and Prevot, A. S. H.: Effects of various meteorological conditions and spatial emissionresolutions on the ozone concentration and ROG/NO $\mathrm{lim}$ itationin the Milan area (I), Atmos. Chem. Phys., 4, 423-438, doi:10.5194/acp-4-423-2004, 2004.

Bhartia, P. K. and Wellemeyer, C.: TOMS-V8 total $\mathrm{O}_{3}$ algorithm, in: OMI Ozone Product ATBD Volume II, NASA Goddard Space Flight Center, Greenbelt, MD, USA, 2002.

Bhartia, P. K., McPeters, R. D., Mateer, C. L., Flynn, L. E., and Wellemeyer, C.: Algorithm for the estimation of vertical ozone profiles from the backscattered ultraviolet technique, J. Geophys. Res., 101, 18793-18806, 1996.

Beekmann, M. and Vautard, R.: A modelling study of photochemical regimes over Europe: robustness and variability, Atmos. Chem. Phys., 10, 10067-10084, doi:10.5194/acp-1010067-2010, 2010.

Benedetti, A., Morcrette, J.-J., Boucher, O., Dethof, A., Engelen, R. J., Fisher, M., Flentje, H., Huneeus, N., Jones, L., Kaiser, J. W., Kinne, S., Mangold, A., Razinger, M., Simmons, A. J., Suttie, M., and the GEMS-AER team: Aerosol analysis and forecast in the European Centre for Medium-Range Weather Forecasts Integrated Forecast System: 2. Data assimilation, J. Geophys. Res., 114, D13205, doi:10.1029/2008JD011115, 2009.

Bloomfield, P., Royle, J. A., Steinberg, L. J., and Yang, Q.: Accounting for meteorological effects in measuring urban ozone levels and trends, Atmos. Environ., 30, 3067-3077, 1996.

Carli, B., Alpaslan, D., Carlotti, M., Castelli, E., Ceccherini, S., Dinelli, B. M., Dudhia, A., Flaud, J. M., Höpfner, M., Jay, V., Magnani, L., Oelhaf, H., Payne, V., Piccolo, C., Prosperi, M., Raspollini, P., Ridolfi, M., Remedios, J., and Spang, R.: First results from MIPAS/ENVISAT with operational level 2 code, Adv. Space Res., 33, 1012-1019, doi:10.1016/S0273-1177(03)005842, 2004.

Chevalier, A., Gheusi, F., Delmas, R., Ordóñez, C., Sarrat, C., Zbinden, R., Thouret, V., Athier, G., and Cousin, J.-M.: Influence of altitude on ozone levels and variability in the lower troposphere: a ground-based study for western Europe over the period 2001-2004, Atmos. Chem. Phys., 7, 4311-4326, doi:10.5194/acp-7-4311-2007, 2007.

Chin, M., Jacob, D. J., Munger, J. W., Parrish, D. D., and Doddridge, B. G.: Relationships of ozone and carbon monoxide over North America, J. Geophys. Res., 99, 14565-14573, 1994.

Courtier, P., Thépaut, J.-N., and Hollingsworth, A.: A strategy for operational implementation of 4D-Var, using an incremental approach, Q. J. Roy. Meteor. Soc., 120, 1367-1388, 1994. 
Crutzen, P. J.: Tropospheric ozone: An overview, in: Tropospheric Ozone, edited by: Isaksen, I. S. A., D. Reidel Publ. Co., 3-32, 1988.

Crutzen, P. J., Lawrence, M. G., and Pöschl, U.: On the background photochemistry of tropospheric ozone, Tellus, 51, 123146, 1999.

Derwent, R. G. and Davis, T. J.: Modelling the impact of $\mathrm{NO}_{x}$ or hydrocarbon control on photochemical ozone in Europe, Atmos. Environ., 28, 2039-2052, 1994.

Dethof, A. and Holm, E. V.: Ozone assimilation in the ERA-40 reanalysis project, Q. J. Roy. Meteor. Soc., 130, 2851-2872, 2004.

Dragani, R.: On the quality of the ERA-Interim ozone reanalyses: comparisons with in situ data, ERA Report Series, 2, available at: http://old.ecmwf.int/publications/library/ecpublications/_pdf/ era/era_report_series/RS_3.pdf (last access: 23 July 2015), 2010.

Dragani, R.: On the quality of the ERA-Interim ozone reanalyses: comparisons with satellite data, Q. J. Roy. Meteor. Soc., 137, 1312-1326, 2011.

Elguindi, N., Clark, H., Ordóñez, C., Thouret, V., Flemming, J., Stein, O., Huijnen, V., Moinat, P., Inness, A., Peuch, V.-H., Stohl, A., Turquety, S., Athier, G., Cammas, J.-P., and Schultz, M.: Current status of the ability of the GEMS/MACC models to reproduce the tropospheric $\mathrm{CO}$ vertical distribution as measured by MOZAIC, Geosci. Model Dev., 3, 501-518, doi:10.5194/gmd-3501-2010, 2010.

EMEP/CCC-Report 1/2005: The development of European surface ozone, in: Implications for a revised abatement policy, edited by: Solberg, S. and Lindskog, A., A Contribution from the EU Research Project NEPAP U-103003, 2005.

Emmons, L. K., Carroll, M. A., Hauglustaine, D. A., Brasseur, G. P., Atherton, C., Penner, J., Sillman, S., Levy II, H., Rohrer, F., Wauben, W. M. F., Van Velthoven, P. F. J., Wang, Y., Jacob, D., Bakwin, P., Dickerson, R., Doddridge, B., Gerbig, C., Honrath, R., Hübler, G., Jaffe, D., Kondo, Y., Munger, J. W., Torres, A., and Volz-Thomas, A.: Climatologies of $\mathrm{NO}_{x}$ and $\mathrm{NO}_{y}$ : A comparison of data and models, Atmos. Environ., 31, 1851-1904, 1997.

Engelen, R. J., Serrar, S., and Chevallier, F.: Four-dimensional data assimilation of atmospheric $\mathrm{CO}_{2}$ using AIRS observations, J. Geophys. Res., 114, D03303, doi:10.1029/2008JD010739, 2009.

Eskes, H. J., van der A, R. J., Brinksma, E. J., Veefkind, J. P., de Haan, J. F., and Valks, P. J. M.: Retrieval and validation of ozone columns derived from measurements of SCIAMACHY on Envisat, Atmos. Chem. Phys. Discuss., 5, 44294475, doi:10.5194/acpd-5-4429-2005, 2005.

Eskes, H., Huijnen, V., Arola, A., Benedictow, A., Blechschmidt, A.-M., Botek, E., Boucher, O., Bouarar, I., Chabrillat, S., Cuevas, E., Engelen, R., Flentje, H., Gaudel, A., Griesfeller, J., Jones, L., Kapsomenakis, J., Katragkou, E., Kinne, S., Langerock, B., Razinger, M., Richter, A., Schultz, M., Schulz, M., Sudarchikova, N., Thouret, V., Vrekoussis, M., Wagner, A., and Zerefos, C.: Validation of reactive gases and aerosols in the MACC global analysis and forecast system, Geosci. Model Dev. Discuss., 8, 1117-1169, doi:10.5194/gmdd-8-1117-2015, 2015.

Flemming, J., Inness, A., Flentje, H., Huijnen, V., Moinat, P., Schultz, M. G., and Stein, O.: Coupling global chemistry transport models to ECMWF's integrated forecast system, Geosci. Model Dev. Discuss., 2, 763-795, doi:10.5194/gmdd-2-7632009, 2009.
Flemming, J., Dethof, A., Moinat, P., Ordonez, C., Peuch, V.H., Segers, A., Schultz, M., Stein, O., and van Weele, M.: Coupling global atmospheric chemistry transport models to ECMWF Integrated Forecasts System for forecast and data assimilation within GEMS, in: Integrated Systems of MesoMeteorological and Chemical Transport Models, edited by: Baklanov, A., Mahura, A., and Sokhi, R., Springer-Verlag, Berlin Heidelberg, doi:10.1007/978-3-642-13980-2_10, 2011.

Fuhrer, J. and Booker, F.: Ecological issues related to ozone: agricultural issues, Environ. Int., 29, 141-154, 2003.

Hegarty, J., Mao, H., and Talbot, R.: Synoptic controls on summertime surface ozone in the northeastern United States, J. Geophys. Res., 112, D14306, doi:10.1029/2006JD008170, 2007.

Hess, P. G. and Zbinden, R.: Stratospheric impact on tropospheric ozone variability and trends: 1990-2009, Atmos. Chem. Phys., 13, 649-674, doi:10.5194/acp-13-649-2013, 2013.

Hollingsworth, A., Engelen, R. J., Textor, C., Benedetti, A., Boucher, O., Chevallier, F., Dethof, A., Elbern, H., Eskes, H., Flemming, J., Granier, C., Kaiser, J. W., Morcrette, J.-J., Rayner, P., Peuch, V. H., Rouil, L., Schultz, M. G., Simmons, A. J., and 5 The GEMS Consortium: toward a monitoring and forecasting system for atmospheric composition: the GEMS project, B. Am. Meteorol. Soc., 89, 1147-1164, 2008.

Inness, A., Flemming, J., Suttie, M., and Jones, L.: GEMS data assimilation system for chemically reactive gases, European Centre for Medium-Range Weather Forecasts (ECMWF), Technical Memoradum No. 587, 2009.

Inness, A., Baier, F., Benedetti, A., Bouarar, I., Chabrillat, S., Clark, H., Clerbaux, C., Coheur, P., Engelen, R. J., Errera, Q., Flemming, J., George, M., Granier, C., Hadji-Lazaro, J., Huijnen, V., Hurtmans, D., Jones, L., Kaiser, J. W., Kapsomenakis, J., Lefever, K., Leitão, J., Razinger, M., Richter, A., Schultz, M. G., Simmons, A. J., Suttie, M., Stein, O., Thépaut, J.-N., Thouret, V., Vrekoussis, M., Zerefos, C., and the MACC team: The MACC reanalysis: an $8 \mathrm{yr}$ data set of atmospheric composition, Atmos. Chem. Phys., 13, 4073-4109, doi:10.5194/acp-13-4073-2013, 2013.

Inness, A., Blechschmidt, A.-M., Bouarar, I., Chabrillat, S., Crepulja, M., Engelen, R. J., Eskes, H., Flemming, J., Gaudel, A., Hendrick, F., Huijnen, V., Jones, L., Kapsomenakis, J., Katragkou, E., Keppens, A., Langerock, B., de Mazière, M., Melas, D., Parrington, M., Peuch, V. H., Razinger, M., Richter, A., Schultz, M. G., Suttie, M., Thouret, V., Vrekoussis, M., Wagner, A., and Zerefos, C.: Data assimilation of satelliteretrieved ozone, carbon monoxide and nitrogen dioxide with ECMWF's Composition-IFS, Atmos. Chem. Phys., 15, 52755303, doi:10.5194/acp-15-5275-2015, 2015.

Joly, M. and Peuch, V.-H.: Objective classification of air quality monitoring sites over Europe, Atmos. Environ., 47, 111-123, 2012.

Kalabokas, P. D., Mihalopoulos, N., Ellul, R., Kleanthous, S., and Repapis, C. C.: An investigation of the meteorological and photochemical factors influencing the background rural and marine surface ozone levels in the Central and Eastern Mediterranean, Atmos. Environ., 42, 7894-7906, doi:10.1016/j.atmosenv.2008.07.009, 2008.

Knowland, K. E., Doherty, R. M., and Hodges, K. I.: The effects of springtime mid-latitude storms on trace gas composition de- 
termined from the MACC reanalysis, Atmos. Chem. Phys., 15, 3605-3628, doi:10.5194/acp-15-3605-2015, 2015.

Komhyr, W. D., Barnes, R. A., Borthers, G. B., Lathrop, J. A., Kerr, J. B., and Opperman, D. P.: Electrochemical concentration cell ozonesonde performance evaluation during STOIC 1989, J. Geophys. Res., 100, 9231-9244, 1995.

Lefever, K., van der A, R., Baier, F., Christophe, Y., Errera, Q., Eskes, H., Flemming, J., Inness, A., Jones, L., Lambert, J.C., Langerock, B., Schultz, M. G., Stein, O., Wagner, A., and Chabrillat, S.: Copernicus stratospheric ozone service, 20092012: validation, system intercomparison and roles of input data sets, Atmos. Chem. Phys., 15, 2269-2293, doi:10.5194/acp-152269-2015, 2015.

Lelieveld, J. and Dentener, F.: What controls tropospheric ozone, J. Geophys. Res., 105, 3543-3563, 2000.

Levelt, P. F., van den Oord, G. H. J., Dobber, M. R., Mälkki, A., Visser, H., de Vries, J., Stammes, P., Lundell, J. O. V., and Saari, H.: The ozone monitoring instrument, IEEE T. Geosci. Remote, 44, 1093-1101, 2006.

Liu, S. C., Trainer, M., Fehsenfeld, F. C., Parrish, D. D., Williams, E. J., Fahey, D. W., Hübler, G., and Murphy, P. C.: Ozone Production in the Rural Troposphere and the Implications for Regional and Global Ozone Distributions, J. Geophys. Res., 92, 4191-4207, 1987.

Monks, P. S.: A review of observations and origins of the spring ozone maximum, Atmos. Environ., 34, 3545-3561, 2000.

Morcrette, J.-J., Boucher, O., Jones, L., Salmond, D., Bechtold, P., Beljaars, A., Benedetti, A., Bonet, A., Kaiser, J. W., Razinger, M., Schulz, M., Serrar, S., Simmons, A. J., Sofiev, M., Suttie, M., Tompkins, A. M., and Untch, A.: Aerosol analysis and forecast in the european centre for medium-range weather forecasts integrated forecast system: Forward modeling, J. Geophys. Res.Atmos., 114, D06206, doi:10.1029/2008JD011235, 2009.

Ordóñez, C., Brunner, D., Staehelin, J., Hadjinicolaou, P., Pyle, J. A., Jonas, M., Wernli, H., and Prevot, A. S. H.: Strong influence of lowermost stratospheric ozone on lower tropospheric background ozone changes over Europe, Geophys. Res. Lett., 34, L07805, doi:10.1029/2006GL029113, 2007.

Ordóñez, C., Elguindi, N., Stein, O., Huijnen, V., Flemming, J., Inness, A., Flentje, H., Katragkou, E., Moinat, P., Peuch, V.-H., Segers, A., Thouret, V., Athier, G., van Weele, M., Zerefos, C. S., Cammas, J.-P., and Schultz, M. G.: Global model simulations of air pollution during the 2003 European heat wave, Atmos. Chem. Phys., 10, 789-815, doi:10.5194/acp-10-789-2010, 2010.

Parrish, D. D., Lamarque, J.-F., Naik, V., Horowitz, L., Shindell, D. T., Staehelin, J., Derwent, R., Cooper, O. R., Tanimoto, H., Volz-Thomas, A., Gilge, S., Scheel, H.-E., Steinbacher, M., and Fröhlich, M.: Long-term changes in lower tropospheric baseline ozone concentrations: Comparing chemistry-climate models and observations at northern midlatitudes, J. Geophys. Res.-Atmos., 119, 5719-5736, 2014.

Penkett, S. A. and Brice, K. A.: The spring maximum in photooxidant in the Northern hemisphere troposphere, Nature, 319, 655657, 1986

Rickard, A. R., Salisbury, G., Monks, P. S., Lewis, A. C., Baugitte, S., Bandy, B. J., Clemitshaw, K. C., and Penkett, S. A.: Comparison of measured ozone production efficiencies in the marine boundary layer at two European coastal sites under different pollution regimes, J. Atmos. Chem., 43, 107-134, 2002.
Savage, N. H., Agnew, P., Davis, L. S., Ordóñez, C., Thorpe, R., Johnson, C. E., O'Connor, F. M., and Dalvi, M.: Air quality modelling using the Met Office Unified Model (AQUM OS24-26): model description and initial evaluation, Geosci. Model Dev., 6, 353-372, doi:10.5194/gmd-6-353-2013, 2013.

Scebba, F., Giuntini, D., Castagna, A., Soldatini, G., and Ranieri, A.: Analysing the impact of ozone on biochemical and physiological variables in plant species belonging to natural ecosystems, Environ. Exp. Bot., 57, 235-246, 2005.

Schaap, M., Cuvelier, C., Hendriks, C., Bessagnet, B., Baldasano, J. M., Colette, A., Thunis, P., Karam, D., Fagerli, H., Graff, A., Kranenburg, R., Nyiri, A., Pay, M. T., Rouïl, L., Schulz, M., Simpson, D., Stern, R., Terrenoire, E., and Wind, P.: Performance of European chemistry transport models as function of horizontal resolution, Atmos. Environ., 112, 90-105, 2015.

Schere, K., Flemming, J., Vautard, R., Chemel, C., Colette, A., Hogrefe, C., Bessagnet, B., Meleux, F., Mathur, R., Roselle, S., Hu, R.-M., Sokhi, R. S., Rao, S. T., and Galmarini, S.: Trace gas/aerosol boundary concentrations and their impacts on continental-scale AQMEII modeling domains, Atmos. Environ., 53, 38-50, 2012.

Schlink, U., Herbarth, O., Richter, M., Dorling, S., Nunnari, G., Cawley, G., and Pelikan, E.: Statistical models to assess the health effects and to forecast ground-level ozone, Environ. Model. Softw., 21, 547-558, 2006.

Siddans, R., Reburn, W. J., Kerridge, B. J., and Munro, R.: Height resolved ozone information in the troposphere and lower stratosphere stratosphere from GOME, Technical report, British Atmospheric Data Centre (BADC), available at: http://cedadocs.badc. rl.ac.uk/97/ (last access: 29 November 2012), 2007.

Stein, O.: Model documentation of the MOZART CTM as implemented in the GEMS system, available at: http://gems.ecmwf. int/do/get/PublicDocuments/1531/1172 (last access: 29 November 2012), 2009

Stein, O., Flemming, J., Inness, A., Kaiser, J. W., and Schultz, M. G.: Global reactive gases forecasts and reanalysis in the MACC project, J. Integr. Environ. Sci., 9, 57-70, doi:10.1080/1943815X.2012.696545, 2012.

Stein, O., Schultz, M. G., Bouarar, I., Clark, H., Huijnen, V., Gaudel, A., George, M., and Clerbaux, C.: On the wintertime low bias of Northern Hemisphere carbon monoxide found in global model simulations, Atmos. Chem. Phys., 14, 9295-9316, doi:10.5194/acp-14-9295-2014, 2014.

Steinbacher, M., Zellweger, C., Schwarzenbach, B., Bugmann, S., Buchmann, B., Ordóñez, C., Prevot, A. S. H., and Hueglin, C.: Nitrogen oxide measurements at rural sites in Switzerland: Bias of conventional measurement techniques, J. Geophys. Res., 112, D11307, doi:10.1029/2006JD007971, 2007.

Stohl, A., Bonasoni, P., Cristofanelli, P., Collins, W., Feichter, J., Frank, A., Forster, C., Gerasopoulos, E., Gäggeler, H., James, P., Kentarchos, T., Kreipl, S., Kromp-Kolb, H., Krüger, B., Land, C., Meloen, J., Papayannis, A., Priller, A., Seibert, P., Sprenger, M., Roelofs, G. J., Scheel, E., Schnabel, C., Siegmund, P., Tobler, L., Trickl, T., Wernli, H., Wirth, V., Zanis, P., and Zerefos, C.: Stratosphere-troposphere exchange - a review, and what we have learned from STACCATO, J. Geophys. Res., 108, 8516, doi:10.1029/2002JD002490, 2003.

Valmartin, M., Heald, C. L., and Arnold, S. R.: Coupling dry deposition to vegetation phenology in the Community Earth System 
Model: Implications for the simulation of surface $\mathrm{O}_{3}$, Geophys. Res. Lett., 41, 2988-2996, 2014.

Valcke, S. and Redler, R.: OASIS4 User Guide (OASIS4 0 2), PRISM-Support Initiative, Technical Report No 4, available at: http://www.prism.enes.org/Publications/Reports/ OASIS4_User_Guide_T4.pdf (last access: 23 July 2015), 2006.

Vestreng, V., Ntziachristos, L., Semb, A., Reis, S., Isaksen, I. S. A., and Tarrasón, L.: Evolution of $\mathrm{NO}_{x}$ emissions in Europe with focus on road transport control measures, Atmos. Chem. Phys., 9, 1503-1520, doi:10.5194/acp-9-1503-2009, 2009.

Volz, A. and Kley, D.: Evaluation of the Montsouris series of ozone measurements made in the nineteenth century, Nature, 332, 240 242, 1988.

Waters, J. W., Froidevaux, L., Harwood, R. S., Jarnot, R. F., Pickett, H. M., Read, W. G., Siegel, P. H., Cofield, R. E., Filipiak, M. J., Flower, D. A., Holden, J. R., Lau, G. K., Livesey, N. J., Manney, G. L., Pumphrey, H. C., Santee, M. L., Wu, D. L., Cuddy, D. T., Lay, R. R., Loo, M. S., Perun, V. S., Schwartz, M. J., Stek, P. C., Thurstans, R. P., Boyles, M. A., Chandra, K. M., Chavez, M. C., Chen, G.-S., Chudasama, B. V., Dodge, R., Fuller, R. A., Girard, M. A., Jiang, J. H., Jiang, Y., Knosp, B. W., LaBelle, R. C., Lam, J. C., Lee, K. A., Miller, D., Oswald, J. E., Patel, N. C., Pukala, D. M., Quintero, O., Scaff, D. M., Van Snyder, W., Tope, M. C., Wagner, P. A., and Walch, M. J.: The Earth Observing System Microwave Limb Sounder (EOS MLS) on the Aura satellite, IEEE T. Geosci. Remote, 44, 1075-1092, 2006.
Wilson, R. C., Fleming, Z. L., Monks, P. S., Clain, G., Henne, S., Konovalov, I. B., Szopa, S., and Menut, L.: Have primary emission reduction measures reduced ozone across Europe? An analysis of European rural background ozone trends 1996-2005, Atmos. Chem. Phys., 12, 437-454, doi:10.5194/acp-12-437-2012, 2012.

Yienger, J. J., Klonecki, A. A., Levy II, H., Moxim, W. J., and Carmichael, G. R.: An evaluation of chemistry's role in the winter-spring ozone maximum found in the northern midlatitude free troposphere, J. Geophys. Res., 104, 3655-3667, 1999.

Zanis, P., Monks, P. S., Schuepbach, E., and Penkett, S. A.: The role of in-situ photochemistry in the control of ozone during spring at the Jungfraujoch Observatory $(3,580 \mathrm{~m}$ asl $)$ - Comparison of model results with measurements, J. Atmos. Chem., 37, 1-27, 2000.

Zanis, P., Ganser, A., Zellweger, C., Henne, S., Steinbacher, M., and Staehelin, J.: Seasonal variability of measured ozone production efficiencies in the lower free troposphere of Central Europe, Atmos. Chem. Phys., 7, 223-236, doi:10.5194/acp-7-223-2007, 2007.

Zanis, P., Hadjinicolaou, P., Pozzer, A., Tyrlis, E., Dafka, S., Mihalopoulos, N., and Lelieveld, J.: Summertime free-tropospheric ozone pool over the eastern Mediterranean/Middle East, Atmos. Chem. Phys., 14, 115-132, doi:10.5194/acp-14-115-2014, 2014. 